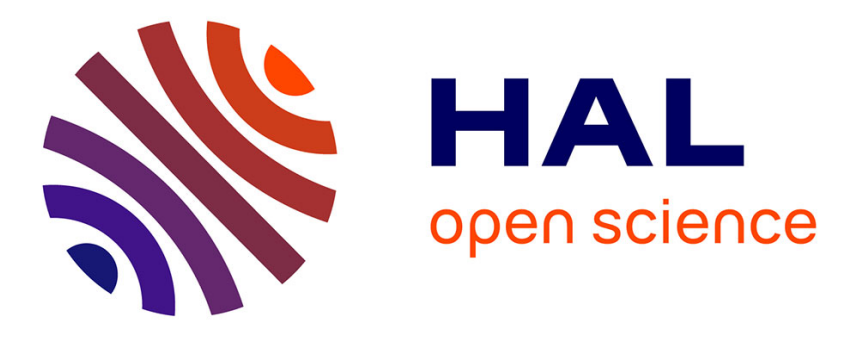

\title{
Fluid systems and fracture development during syn-depositional 1 fold growth: an example from the Pico del Aguila anticline, Sierras Exteriores, Southern Pyrenees, Spain.
}

Nicolas Beaudoin, Damien Huyghe, Nicolas Bellahsen, Olivier Lacombe, Laurent Emmanuel, Frédéric Mouthereau, Laure Ouanhnon

\section{To cite this version:}

Nicolas Beaudoin, Damien Huyghe, Nicolas Bellahsen, Olivier Lacombe, Laurent Emmanuel, et al.. Fluid systems and fracture development during syn-depositional 1 fold growth: an example from the Pico del Aguila anticline, Sierras Exteriores, Southern Pyrenees, Spain.. Journal of Structural Geology, 2015, 70, pp.23-38. 10.1016/j.jsg.2014.11.003 . hal-01083732

\section{HAL Id: hal-01083732 \\ https: / hal.sorbonne-universite.fr/hal-01083732}

Submitted on 18 Nov 2014

HAL is a multi-disciplinary open access archive for the deposit and dissemination of scientific research documents, whether they are published or not. The documents may come from teaching and research institutions in France or abroad, or from public or private research centers.
L'archive ouverte pluridisciplinaire HAL, est destinée au dépôt et à la diffusion de documents scientifiques de niveau recherche, publiés ou non, émanant des établissements d'enseignement et de recherche français ou étrangers, des laboratoires publics ou privés. 
1 Fluid systems and fracture development during syn-depositional fold growth: an example from the Pico del Aguila anticline, Sierras Exteriores, Southern Pyrenees, Spain.

Nicolas Beaudoin ${ }^{1,2,3,}$, Damien Huyghe ${ }^{4}$, Nicolas Bellahsen ${ }^{1,2}$, Olivier Lacombe ${ }^{1,2}$, Laurent Emmanuel1,2, Frédéric Mouthereau1,2, Laure Ouanhnon ${ }^{1,2}$. 1 Sorbonne Universités,UPMC Univ Paris 06, UMR 7193, ISTEP, F-75005, Paris, France.

82 CNRS, UMR 7193, F-75005, Paris, France.

93 School of Geographical and Earth Sciences, University of Glasgow, Gregory Building, 10 G128QQ Glasgow, United Kingdom.

114 UMR 5563 - Geosciences Environnement Toulouse, Université Paul Sabatier Toulouse 12 III, Toulouse, France.

Keywords: Fluid system; Syn-sedimentary fold development; Pyrenean foreland; Fracture population; Sierras Exteriores ; Pico del Aguila anticline.

\section{Abstract}

This paper reports an integrated, spatio-temporal analysis of the fracture-controlled paleo-fluid system in the Pico del Aguila anticline, a N-S trending fold located in the Sierras Exteriores, the southern front of the Spanish Pyrenees. Eight fracture sets (joints or faults) are recognized throughout the fold and are separated into a fracture sequence that is defined using field relationships and the remarkable temporal constraints offered by the syn-tectonic sedimentary deposits. This fracture sequence records a complex Paleocene to Early Oligocene structural evolution, including map-view, clockwise rotation and tilting of the fold axis. The geochemical analysis of calcite cements from the different mineralized fracture/vein sets reveals a compartmentalized fluid system during most of fold development. This initial paleofluid system was later perturbed when bending-related fractures associated with foreland flexure and outer arc extension triggered small-scale, vertical fluid migration. Fractures developed in shallow strata facilitated downward migration of surficial fluids that controlled the paleo-fluid system in the Late Priabonian/Stampian continental deposits. The study of the Pico del Aguila anticline depicts for the first time the evolution of a fluid system in a shallow, syn- 
fluids migrate vertically across stratigraphic boundaries take place during fold hingerelated deformation.

\section{Introduction}

Fluid-rock interactions during folding control diagenesis and deformation, hydrocarbon migration, and heat transport (Qing and Mountjoy, 1992; Roure et al., 2005; Katz et al., 2006; Lacombe et al., 2014). A recent review of factors governing the temporal and spatial distribution of fluids in folds (Evans and Fischer, 2012) highlights that the development of a sub-seismic fracture network is essential in fluid migration. In particular, the vertical persistence and lateral connectivity of joints usually promotes alternating vertical and lateral fluid migrations at local and large-scale (e.g. Evans and Battles, 1999; Van Geet et al., 2002; Fischer et al., 2009; Barbier et al., 2012a; Beaudoin et al., 2011, 2014). Although no simple rule arises since each natural case of foldfracture-fluid interactions differs, a common characteristics occurs (Evans and Fischer, 2012): the development of curvature-related fracture sets promotes vertical fluid migration and mixing of various preexisting hydrologic reservoirs delimited by stratigraphic seals. This kind of evolution can be deciphered when both the large faults and the fracture network are studied. Indeed, sub-seismic fracture patterns experience a succession of deformation steps at fold-scale (Stearns and Friedman, 1972; Fischer and Wilkerson, 2000; Bergbauer and Pollard, 2004; Bellahsen et al., 2006a, b; Cooper et al., 2006; Tavani et al., 2006; Beaudoin et al., 2012, 2013). However, most studies were performed in settings where deformation substantially postdates strata compaction (Evans and Battles, 1999; Van Geet et al., 2002; Fischer et al., 2009; Beaudoin et al., 2011, 2014; Barbier et al., 2012a). Consequently, the evolution of fluid-rock interactions in strata folded at shallow depth during sediment deposition remains incompletely documented.

Here, we study the case of the Pico del Aguila anticline, one of the N-S trending folds of the Sierras Exteriores positioned at the southern structural front of the Pyrenees (Fig. 1). The Pico del Aguila anticline is interpreted as a detachment fold with a décollement level located within Triassic evaporitic rocks (Millán, 1996). The growth of the structure is recorded by the syn-tectonic deposition of deep marine to continental sediments from the Late Lutetian to Priabonian times (Millán et al., 1994; Hogan and Burbank, 1996; Castelltort et al., 2003). The kinematics and mechanics of the Sierras 
Exteriores and especially the Pico del Aguila anticline have been extensively documented (Millán et al., 1994; Poblet and Hardy, 1995; Poblet et al., 1998; Novoa et al., 2000; Anastasio and Holl, 2001; Castelltort et al., 2003; Nalpas et al., 2003; Huyghe et al., 2009; Vidal-Royo et al., 2012, 2013). Our investigation of the fluid system in the southernmost fold structures of the Pyrenean foreland allows a comparison with recent studies of fluid systems in the northern hinterlandward fault-related folds (Travé et al., 2000, 2007; Lacroix et al., 2011, 2014).

This contribution aims to describe the fracture network in the Pico del Aguila anticline, and then using the remarkable record of fold evolution granted by the growth strata to decipher the history of fracturing. Geochemical analyses of calcite vein cements as well as fault-coating calcite are used to identify and interpret the sources of fluids that flowed in fractures, their pathways, and their interactions with surrounding rocks. Beyond regional implications, results shed light on the evolution of the paleo-fluid system during growth of syn-depositional detachment folds.

\section{Geological Setting}

The Pico del Aguila anticline is a $160^{\circ} \mathrm{E}$ trending anticline located in the Sierras Exteriores, a range comprising a set of NW-SE to N-S trending folds markedly oblique to the south-Pyrenean thrust front (Fig. 1). The Sierras Exteriores are located at the southern front of the Jaca piggyback basin, which borders the southwestern part of the Central Pyrenees. The Pico del Aguila anticline plunges $30^{\circ}$ toward the North, because it is linked to the late thrusting of the Jaca Basin over the Ebro basin during the activation of the Guarga basement thrust (Fig. 1B, Teixell, 1996; Jolivet et al., 2007). The Pico del Aguila anticline is a detachment fold with a décollement level located within the Triassic evaporite strata (Fig. 2). The growth of this anticline is well-constrained by the wealth of biostratigraphic data (Canudo et al., 1988; Molina et al., 1988; Sztràkos and Castelltort, 2001; Huyghe et al., 2012a) and paleomagnetic studies (Hogan and Burbank, 1996) obtained on Middle Eocene to Oligocene growth strata. The sedimentary succession (Fig. 1C) comprises dolostones and gypsiferous clays composing the Triassic Muschelkalk and Keuper facies, respectively (Millán et al., 1994). The overlying formations are the upper Cretaceous platform limestones of the Adraén-Bona Formation (Fm.), the Paleocene continental and fluvial sandstones and mudstones of the Tremp Fm., and the 
Lutetian shallow marine limestones of the Guara Fm. The sedimentary record indicates

104 that folding began during the deposition of the upper part of the Guara Fm. (upper 105 Lutetian, Millán et al., 1994; Huyghe et al., 2012a) and lasted during deposition of the 106 Bartonian-early Priabonian prodeltaic marls of the Arguis Fm. and the Middle107 Priabonian marine shallow-deltaic sandstone of the Belsué-Atarès Fm. This 108 interpretation is in accordance with the growth model of Hogan and Burbank (1996) 109 that indicates that folding began during the late Lutetian (42 Ma) and ended during early 110 Priabonian (35 Ma). On top of the latter formation, the Late Priabonian-Stampian 111 continental sandstones and claystones of the Campodarbe Fm. were deposited after 112 folding (Millán et al., 1994). Subsequent thrusting of the Jaca basin over the Ebro basin is 113 due to the development of the southern Pyrenean frontal thrust during Late Oligocene114 early Miocene (Millán, 1996; Jolivet et al., 2007; Huyghe et al., 2009).

\section{Methodology to decipher fluid-fracture-fold evolution}

This work focuses on fracture generations observed in pre-, syn- and post-folding strata of the Pico del Aguila anticline. Fracture generations are mainly composed of joints and veins opened in mode I, as well as faults along which movement is recorded

121 by slickensides. Pressure-solution seams (stylolites) related to both compaction and

122 tectonic loading also occur. Mode I-opening of joints and veins was checked in the field 123 and in thin-sections by the offset of pre-existing elements in the matrix or by the lack of 124 grain crushing in the matrix near the borders of the fractures (Fig. 3a).

125 Nearly 1500 joint/vein orientation data were collected along with 120 fault-slip data at 126 the outcrop-scale (Fig. 4-7, Table S2 as supplementary material) in different formations 127 (pre-, syn-, and post-folding strata extending from Triassic to Priabonian) and structural 128 positions (hinge and limbs). About 50 sites were defined by a common structural 129 position and bedding dip, half of them being located in the pre-folding strata (25 sites). 130 The post-folding strata of the Campodarbe Fm. have fewer samples in our dataset (6 131 sites).

\section{1. Identification of fracture sets}

134 Identification of fracture sets is now a well-established and powerful tool to 135 unravel the deformation history of folded strata (eg, Bergbauer and Pollard, 2004; 
136 Bellahsen et al., 2006; Lacombe et al., 2012). Fracture sets can be defined as fracture

137 populations that share a common deformation mode, a common orientation regarding

138 the bedding dip and with statistically consistent chronological relationships compared

139 to other fracture sets. For our study, we compute the mean orientation of measured

140 fractures for each site by means of a Kernel statistical analysis (software developed at

141 IFPEN for the definition of fracture sets, see Bellahsen et al., 2006; Ahmadhadi et al.,

142 2008). This data processing is first done for the present position of strata, then after the

143 correction of the fold axis plunge (by removing the tilt of $30^{\circ}$ due to the frontal thrust

144 activity), and in a third step after the removal of the local bedding dip. Results are

145 presented on stereonets for each measurement site at each step (Figs. 3 to 6). Diagrams

146 are not weighted by abundance, as we believe that this modification can be biased by

147 outcrop conditions. However, vertical persistence, spacing or relative abundance of

148 fractures all were considered for the interpretations. Indeed, we believe that a fracture

149 set is relevant to constrain the tectonic evolution of strata only if it is observed

150 everywhere in the fold, or at least in numerous sites from a single structural or

151 stratigraphic position. Therefore, data processing results in the recognition of different

152 fracture sets that are each related to a deformation event. We assume that the

153 development of a fracture set will not overlap the development of another fracture set

154 except if the stress conditions required are similar for these two sets and if

155 chronological relationships suggest synchronism. Consequently, we use chronological

156 relationships to constrain the development of fracture sets through time so to build the

157 fracture sequence.

158 Four approaches are used to determine the relative age of the different fracture

159 sets: (a) the relative age of fractures based on abutting or offset relationships at field

160 sites; (b) the restriction of fractures to particular units in the pre-, syn- and/or post-

161 folding stratigraphic sequence; (c) the assumption that mode I fractures formed

162 vertically with a horizontal least compressive principal stress (Anderson, 1951); and (d)

163 the assumption that bed-perpendicular fractures striking parallel to the fold axis and

164 located near the hinge of the fold are related to local extension due to strata bending. We

165 carefully observed abutments and crosscutting relationships on pavements at the Pico

166 del Aguila, using a rule that a set composed of fractures that terminate at fractures of

167 another set are inferred to have developed later (Fig. 8). These relationships observed at

168 site-scale are checked on thin sections, and the consistency of the chronology is checked 
169

170

171

172

173

174

175

176

177

178

179

180

181

182

183

184

185

186

187

188

189

190

191

192

193

194

195

196

197

198

199

200

201

at the fold-scale. Finally, the sequence is checked with the record provided by growth strata.

\subsection{Inversion of fault-slip data for paleostress}

Some fracture sets comprise only faults, which slips were inverted to reconstruct the related stress tensor using the inversion methods described in Angelier (1984)(see Lacombe, 2012 for a recent review of fault-slip data inversion for paleostresses). The identification and separation of successive generations of faults and related stress regimes are based on both mechanical incompatibility between individual fault slips (with the computed stress tensor) and relative chronology observations (e.g., superimposed striations on fault surfaces, crosscutting relationships between faults). As with the fracture sets, we provide stereonets to show the results of fault-slip data inversion (1) in the current strata attitude (post-thrusting); (2) after removing the regional tilt of the fold axis due to the activation of the frontal thrust (pre-thrusting and post-folding); (3) and after removing the local bedding dip (pre-folding). If one assumes that a principal stress axis remains generally vertical without local stress rotations, which could be due to stress channelization within shallow-dipping strata separated by low friction interlayers along which bedding-parallel slip occurs (Tavani et al., 2006), (1) inversion of a fault set formed before folding (or thrusting) and measured in a fold limb would have one of the computed stress axes perpendicular to bedding, with the other two lying in the bedding plane; (2) inversion of a post-folding or post-thrusting fault set yields stress tensors with compression horizontal irrespective of bedding dip in the current or pre-thrusting attitude (e.g., Lacombe, 2012). Note that pre-folding stress tensors are presented on Schmidt's stereonets only in cases where stress axes are consistent with these Andersonian conditions once corrected from plunge and/or bedding dip.

\subsection{Petrographic and geochemical analyses of veins and host-rock cements}

Samples of vein calcite cements and fault-coating calcite within their surrounding matrix were collected in a variety of stratigraphic and structural positions. We use standard and cathodoluminescence petrography, as well as stable isotopes of carbon and oxygen to constrain the geochemistry of the fluids from which calcite precipitated. 
Although we observe fluid inclusions in the samples, microthermometric work proved

203 fruitless, and yielded only the observation that the inclusion population was dominated

204 by monophase (liquid), aqueous inclusions (Fig 3 e-f) where the attempts to nucleate 205 vapor bubble by freezing failed. Lack of vapor bubble in inclusions suggests a 206 precipitation of fluids about $80 \pm 20^{\circ} \mathrm{C}$ (Roedder, 1984).

Petrographic and cathodoluminescence observations were conducted on oriented thin-sections of 35 selected samples that are representative of fracture sets observed at the Pico del Aguila anticline. We use observations of vein crystal textures and offset wall-rock markers to constrain the mode of fracture wall displacement (Fig. 3). Microscopy also allowed checking and refining the chronological relationships that have been initially defined from field observations. We use a Cathodyne Opea cold cathode system to examine the cathodoluminescence of the samples (Fig. 9). These observations constrain the number of precipitation events, the conditions of precipitation, and the diagenesis of the veins and host rocks. Operating conditions are in the range of 200-400 lA and 13-18 kV gun current with a constant 60 mTorr vacuum.

$\delta^{18} \mathrm{O}$ and $\delta^{13} \mathrm{C}$ have been measured in calcite collected from 70 veins and related host-rocks, covering various structural and stratigraphic positions in the Pico del Aguila anticline (Fig. 10, Table S1). Measurements are performed using an automated preparation device coupled to an Isoprime gas-ratio mass spectrometer. Between 40 and $100 \mu \mathrm{g}$ of calcite powder is collected from each veins, using either hand-drill or scalpel to avoid mixture with host-rocks. Samples are placed in glass vials and reacted with dehydrated phosphoric acid under vacuum at $90^{\circ} \mathrm{C}$, before being measured 10 times each. A correction for dolomite samples was conducted (Rosenbaum and Sheppard, 1986). Hereinafter, all values for both veins and host-rocks are reported in per mil (\%) relative to the Vienna Pee Dee Belemnite (VPDB or PDB) for carbon and for oxygen with an accuracy of $0.05 \%$ and $0.1 \%$, respectively (Table S1).

\section{Fracture system: observations and interpretations}


Puigdefabregas, 1975; Millán, 1996; Vidal-Royo et al., 2012). The main difference is that

236 Triassic rocks are not observed in the northern part of the fold where sub-vertical limestone strata of the Cretaceous Adraen-Bona Fm. were observed.

Eight fracture sets are defined by field observations, statistical analyses, and stress inversion processes, including 5 joint/vein sets (Figs. 4-6) and 3 striated fault sets (Fig. 7). For the sake of simplicity, the fracture sequence is presented with a nomenclature defined by relative timing with respect to folding (Fig. 8).

242 Sets J1 and J2 appear mainly in the oldest pre-tectonic formation (Table 1, figs. 4-5-

243 6), making them the oldest fractures to have developed. Both are bed-perpendicular.

244 Once the plunge and local dip are removed, set J1 strikes $120^{\circ}$ while set J2 strikes $090^{\circ}$.

245 Cross-cutting relationships show younger J2's abutting against older J1's (Fig. 8-b). Other sets are observed in all stratigraphic units. Set J3 joints and veins strike $070^{\circ}$ and are bed-perpendicular, and abut against set J2 fractures (Fig. 8-c). Set J4 joints and veins strike $40^{\circ}$ and are bed-perpendicular, reopen J3 fractures and abut against J2 fractures (Fig. 8-c). Sets J3 and J4 are observed in every structural position, whereas set J5 is only observed near the anticline hinge and in the syncline. Set J5 joints and veins are roughly normal to bedding and strike mainly $170^{\circ}$. Chronological relationships from outcrops and thin sections indicate that set J5 is younger than sets J1, J2, J3, and J4 (Fig 8-a,d), whereas chronological relationships with set J4 are ambiguous.

Sets F1, F2 and F3 comprise faults that are defined by a common causative paleostress reconstructed using a stress inversion process (Fig. 7). Because the lack of crosscutting relationships, the chronology of these fault sets is poorly constrained by field and petrographic observations. Age of the fault sets with respect to folding and thrusting events can however be assessed by assuming that they developed when the stress tensor has a vertical principal stress, as predicted by Anderson (1951). Set F1 comprises steeply dipping, N-S striking normal faults that were only observed at the fold hinge, and developed under an E-W extensional stress regime during folding (Fig. 7). Set F2 comprises newly-formed N-S reverse faults (ex: site 434, Fig. 7) with strike-slip reactivation of fractures oriented $045^{\circ} \mathrm{E} / 060^{\circ} \mathrm{E}$ (ex: site 433-2, Fig. 7) and $160^{\circ}$ (ex: 474,

264 Fig. 7), and are compatible with a nearly E-W compression which respect to Anderson's theory in the current attitude of strata or just plunge-corrected, meaning they developed since post-folding. Lastly, set F3 comprise a group of conjugate E-W reverse faults that formed in a predominantly N-S compressional stress regime (ex: site 136-1, Fig. 7). 
268 These faults developed after folding, some of them postdate thrust activation (ex: site

269 136-1, Fig. 7) while the observed orientation, motion and steep angle of some other 270 reverse faults (ex: site 34, Fig. 7) suggests that they developed at a lower angle during 271 the thrusting.

Prior work has shown that the area of the southern Pyrenean thrust front

274 experienced rotation around a vertical axis. This rotation is interpreted as being related to the southwestward propagation of the deformation in the south Pyrenees and is believed to partially explain the N-S striking of the folds in the Sierras Exteriores. Rotations of $15^{\circ}$ to $50^{\circ}$ have been proposed from paleomagnetic studies (Pueyo et al., 2002; Oliva-Urcia and Pueyo 2007) and on displacement field reconstruction (Huyghe et al., 2009). Timing of such a rotation for the Pico del Aguila area is inferred to have started as soon as Bartonian and terminated during Oligocene times (Huyghe et al., 2009).

Consequently, this rotation history is of primary importance for interpreting the fracture sequence with respect to anticline development (Fig.11). Drawing on timing of sedimentation with respect to folding (Fig. 1B), and on the stratigraphic distribution of the fracture sets (Figs. 3 to 8, Table 1), we propose that the progressive development of fractures from a $090^{\circ}$ strike (set J2 only in oldest strata) to a $040^{\circ}$ strike (set J4 in all strata) reflects a progressive clockwise rotation (Fig. 11). Joint sets J2 to J4 are inferred to have formed sequentially parallel to the direction of maximum contraction as part of the structural suite recording regional layer-parallel shortening (LPS) that we here documented as striking NE-SW (Fig. 11-a-b-c (2)). This interpretation is based on (1) the established existence of a rotation in the area, (2) the fact that set J2 is a bedperpendicular, fold-axis perpendicular-striking set of joints which can be related to LPS (e.g. Bellahsen et al., 2006a), and (3) the stratigraphic distribution of fracture sets, where J2 is observed only in prefolding and prerotation Guara Fm. (Huyghe et al., 2009) while J3 and J4 developed also in syn-rotation strata (Table 1). The angular difference in present-day strikes for sets $\mathrm{J} 2$ to $\mathrm{J} 4$ is $50^{\circ}$, which we infer to reflect the maximum magnitude of the rotation around a vertical axis (Fig.11-a-b-c). Our interpretation differs from previous work that predicts a rotation of only $20^{\circ}$ at the Pico del Aguila (Huyghe et al., 2009). Considering our data, because of possible local heterogeneities and bed-scale stress perturbations, the strikes of fracture sets are only given within $10^{\circ}$ of accuracy 
(Table 1). Given this limitation and considering mean strikes for each fracture set, the

302 minimal value for the vertical rotation is the difference between J2's $\left(80^{\circ}\right)$ and J4's $\left(50^{\circ}\right)$

303 strikes. Therefore, our dataset suggests a vertical rotation of about $30^{\circ}$ and is more 304 likely considering results from other studies (Pueyo et al., 2002; Oliva-Urcia and Pueyo 2007, Huyghe et al., 2009).

We infer that set $\mathrm{J} 1$ predates the rotation and its final orientation fully records the rotation. Given a present day strike of $120^{\circ}$, the regional trend of $\mathrm{J} 1$ before the rotation would be $090^{\circ}$ (Fig. 11-a (1)). Thus, the joints could be interpreted as having developed during N-S extension related to foreland flexure and/or forebulge in the area (Hervouët et al., 2005). Set J5 is inferred to have developed at the anticline hinge during outer-arc bending that occurred during vertical axis rotation. As these fractures reflect hinge-related deformation, their orientation remained parallel with the anticlinal hinge as it rotated (Fig. 11 a-b-c). Similarly, during fold growth, hinge extensional strain was accommodated by development of F1 faults that were also rotated with the anticline as it grew and spun (Fig. 11-c (3)). Crosscutting relationships between J4 and J5 are ambiguous, so the development of J4 fractures parallel to regional contraction could have been before or coeval with local extension at the hinge.

After rotation around a vertical axis was completed (Fig. 11-d (4)), fold tightening locally perturbed tectonic stress that became perpendicular to fold axis (e.g., Amrouch et al., 2010), in response to which set F2 formed. Later, the Pyrenean-related N-S contraction triggered E-W-trending thrusts ramps (Teixell, 1996; Jolivet et al., 2007), tilted the folds axis during its overthrusting above the $30^{\circ}$-dipping frontal ramp and caused E-W small reverse F3 faults (Fig. 11-d (5)).

The proposed fracture sequence reflects a tectonic history starting from foreland flexure and/or forebulge until the late activation of regional thrusts due to Pyrenean N-S orogenic contraction. Similar relationships between regional-scale foreland flexure and the development of systematic sets of parallel joints/veins have been proposed in other foreland basins (Billi and Salvini, 2003; Beaudoin et al., 2012; Quintà and Tavani, 2012), and supports a growing body of evidence that many fractures observed in folded strata may in fact predate folding history (e.g., Bergbauer and Pollard, 2004; Bellahsen et al., 2006a; Ahmadhadi et al., 2008; Lacombe et al., 2011; Quinta and Tavani, 2012).

\section{Fluid system: observations and interpretations}




\subsection{Sample selection according to microstructural observations}

Using observations of veins and surrounding host-rocks from optical and cathodoluminescence microscopy (Fig. 3, 9), four different textures in veins can be described, following the classifications of Durney and Ramsay (1973) and Machel 339 (2000).

340 The textures are (1) blocky calcite with single-phase, bright orange luminescence with 341 brighter fringes at the external rim of crystals (Fig. 9-a); (2) blocky calcite with grain342 scale luminescence zonation from bright to dull orange luminescence (Fig. 9-b); (3) 343 Elongated blocky veins with orange luminescence variation in the vein while each 344 fibrous crystal has homogeneous luminescence (Fig. 9-c); and (4) Crack-seal textures characterized by fringes of fine stretched grains on the outer bound of the vein recording one single (Fig. 3-d) or multiple (Fig. 3-a) events. The four textures are observed in all veins sets, so correlation does not exist between texture and either with stratigraphic position or structure or vein set, suggesting precipitation mechanisms independent from these parameters.

Textures in veins can be used as indicators of mode I opening and for a single event of fluid precipitation. Blocky calcite texture showing growth competition (Fig. 3-d) is symptomatic of a single fluid precipitation event (Bons et al., 2012). Most of veins from our samples displays such a texture, and cathodoluminescence observed in case

354 (1) (Fig. 9-a) is related to dynamic recrystallization due to growth competition (Machel, 2000), while small-scale zonation of case (2) reflects slower precipitation under variable redox condition or simply variation in precipitation kinetics (Machel, 2000). Elongated blocky veins described as texture (3) (Figs. 3-b, 9-c) can be interpreted to reflect precipitation kinetics of fluid equivalent to opening kinematics of the fracture (Bons et al., 2000). Also, the elongation direction relates to the direction of opening of veins, and is useful to distinguish mode I veins fractures (Fig. 3-b) from oblique opening veins fractures (Fig. 3-a), where the latter were discarded from our geochemical study. Finally, multiple crack-seal events were discarded for geochemistry (Fig. 3-a) as they reflect multiple or discontinuous fluid precipitation events, possibly involving different sources

364 (Bons et al. 2000). 
To interpret the geochemical dataset in terms of fluid system evolution, we divided the data into pre-, syn-, and post-folding groups based on host stratigraphic units to determine if isotopic data from veins and host rock show correlations with stratigraphy and/or fold timing (Fig. 10, Table 2). Considering the data this way, we identify four patterns: (1) Veins from Triassic Fms. and some veins from pre-folding

372 Guara Fm. exhibit $\delta^{18} \mathrm{O}$ and $\delta^{13} \mathrm{C}$ values lower than those of their host-rocks; (2) all other veins belonging to pre-folding formations exhibit $\delta^{18} 0$ values lower than those of their host-rocks, while simultaneously exhibiting $\delta^{13} \mathrm{C}$ values that are broadly similar to those of their host-rocks. (3) Veins in the syn-folding Arguis Fm. have $\delta^{18} 0$ and $\delta^{13} \mathrm{C}$ similar to their host-rock values. (4) Veins from the post-folding Campodarbe Fm. exhibit $\delta^{18} 0$ values that are significantly greater than their host-rock values, but $\delta^{13} \mathrm{C}$ values similar to their host-rock values. These four patterns in the data suggest that fluids from different sources interacted with the host-rocks before, during and after folding, such that fluid flow and precipitation were a function of stratigraphic interval and deformation timing.

Isotopic disequilibrium in vein cements that belong to pattern (1) suggests an opening of each reservoir to an external source of fluids, characterized by negative $\delta^{13} \mathrm{C}$ values. As shown in Fig. 10-a, the low $\delta^{13} \mathrm{C}$ values in some Guara Fm. and Triassic veins seem to match those of host rocks in the Paleocene Tremp Fm, and we note that the negative $\delta^{13} \mathrm{C}$ values are consistent with sedimentary rocks inferred to represent paleosoils and lakes (Pujalte et al., 2009) that contain organic matter. The shallow burial depth attained in this area makes it unlikely that the lower $\delta^{13} \mathrm{C}$ values in veins reflect the influence of hydrocarbons. Instead, we infer paleohydrological connection and mixing between fluids from these Paleocene and Triassic units. Interestingly, this connection is recorded broadly in veins of sets J1 and J5, meaning that most of the vertical fluid migration between units was triggered by curvature-related fractures, either due to folding or to regional foreland flexure (Fig. 12-a).

Isotopic patterns of cases (2) and (3) reflect a closed stratified fluid system that experienced a different evolution regarding the timing of deposit of host-rock regarding evolution of folding (Fig. 10-a,-b):

397 - Veins in pre-folding formations that are not case (1) can be defined by isotopic pattern 398 (2). The lower $\delta^{18} 0$ of veins relative to host rocks can be interpreted resulting from 399 precipitation of local fluids after a burial (e.g. Ferket et al., 2000; Travé et al., 2007; Fitz- 
Diaz et al., 2011; Evans et al., 2012; Vandeginste et al., 2012). According to the isotopic difference between veins and host-rocks ( $\Delta$ on Fig. 10-b) and considering temperaturedependent fractionation between $\mathrm{H}_{2} \mathrm{O}$ and $\mathrm{CaCO}_{3}$ after Kim and O'Neil (1997), we estimate that pore fluids precipitated $30^{\circ} \mathrm{C}$ higher than host-rock precipitation temperature. Considering "normal" geothermal gradient, this interpretation implies a burial of $1 \mathrm{~km}$, consistent with the sedimentary history (Vidal-Royo et al., 2012).

- Syn-folding formation is characterized by an isotopic equilibrium between veins and host-rocks (case (3)) that reflects local pore-fluids precipitation without significant change in temperature since host-rock underwent diagenesis. This is consistent with the limited burial experienced by the Arguis Fm. after it deposited in the area of the Pico del Aguila (Millán, 1996).

The isotopic pattern of case (4) in the post-folding Campodarbe Formation is inferred to represent an opening to external source of fluids characterized by a higher $\delta^{18} \mathrm{O}$ values. According to the continental paleo-environmental conditions at that time (Millán, 1996), such a source could be either river-derived fluid or meteoric fluids. As river-derived fluids isotopic range cannot be used to explain the measured signatures ($8 \%$ to $-5.5 \%$ PDB, Zamarreno et al., 1997, Huyghe et al., 2012b), we propose that isotopic signatures of case (4) record precipitation from meteoric fluids.

\section{Discussion : fluid-rock evolution during syn-depositional folding}

In their recent review focusing on fold-related fluid systems, Evans and Fischer (2012) stressed the fact that these fluid systems have some common characteristics before and during folding. Analysis of paleo-fluid systems during growth of both detachment and basement-cored folds show that fluid systems are compartmentalized by stratigraphy and exhibit little vertical fluid migration. During subsequent folding, syn-folding joints and faults rupture stratigraphic seals and trigger vertical fluid migration and mixing.

The fluid system evolution of the Pico del Aguila (Fig. 12-a) is accordingly interpreted as a stratified fluid system during most of the geological history, with a strong control of lithology on the fluid isotopic signatures (e.g. Fischer et al., 2009; Evans

431 and Fischer, 2012). However, inter-formational fluid flow is documented for sets J1 and 432 J5, which are related to flexural forebulge and local extension due to folding, 
respectively. Once the paleo-environment switches from marine to continental during Priabonian (Millán, 1996), the source for formational fluid switched from marinederived pore fluids to surficial, likely meteoric-derived fluids.

The likely common opening of fluid systems to vertical migration during folding (e.g., Evans and Fischer, 2012, Fig.12) is therefore once more supported by the Pico del Aguila case study. Opening during flexural forebulge has also been documented in the Bighorn Basin (Beaudoin et al., 2014). Being the first syn-depositional fold developed at shallow depth for which the fluid system has been studied, the Pico del Aguila additionally illustrates, beyond the strong lithological control on the fluid system, the progressive switch from marine to continental environment as documented by $\delta^{18} 0$ values of calcite-cemented veins. This interpretation is consistent with observations of current fluid flow in anticlines developed at shallow or significant water depth as in the Central Basin in Iran or in Brunei (Morley et al., 2014). The difference in burial depth at the time of deformation also impacts on the scale of the vertical migration triggered by effective tension-related fracture sets (Fig. 12). For example in a deep buried basementcored fold, such as the Sheep Mountain anticline (Fig. 12-a, Beaudoin et al., 2011), curvature-related fractures developed enough vertical permeability to allow fluid from depth to invade all the strata, while such big-scale migration is not recorded for the Pico del Aguila (Fig. 12-b). This difference could be directly related to the limited burial and related mechanical compaction of the reservoir, and could illustrate the influence of mechanical properties of strata on hydraulic behavior of curvature related fractures, as highlighted in numerous natural cases (Cooke, 1997; Fischer and Jackson, 1999; Laubach et al, 2009; Savage et al., 2010; Barbier et al., 2012a; b; Morley et al., 2014).

More generally, studies of regional fluid flows in the southern Pyrenean foreland depict large-scale flows of hydrothermal fluids in structures closer to the Pyrenean range (Travé et al., 2000; 2007), and in the Gavarnie thrust, structurally above the Guarga thrust (McCaig et al. 1995; Henderson and McCaig, 1996; McCaig et al., 2000). In the Pico del Aguila, no hydrothermal fluid flow overprinted the system during activation of the underlying Guarga thrust that developed set F3 faults, in which syn-kinematic calcite coating precipitated from local fluids (Table S1). The lack of evidence of deep fluid flow has also been documented along the thrust system of the Monte Perdido, South of Gavarnie (Lacroix et al., 2011) and can be related to the large distance from the range (Figure 1, Lacroix et al., 2014). Alternatively, this lack could be related to limited 
faults and joints development after folding. The related vertical permeability creation was too limited and prevented fluids from the basement to flow through the nonpermeable evaporites underlying the limestone. Such a case is opposed to what can happen in a basement-cored fold (Fig. 12-a).

\section{Conclusions}

1. The sub-seismic fracture pattern recognized in folded strata of the Pico del Aguila anticline comprises 8 sets of joints/veins and faults. The oldest fracture set is likely related to the regional-scale foreland flexure that affected strata during Lutetian and therefore clearly predates folding history. Three fracture sets (J2 to J4) then developed in progressively youngering strata, recording a clockwise vertical-axis rotation of the area. Their E-W to NE-SW trends indicate that they developed under a far-field, relatively static NE-SW shortening during the $30-40^{\circ}$ rotation around a vertical axis. Among the four remaining sets, two are related to local outer-arc extension during folding (sets J5 and F1), one is related to E-W compression during late-stage fold tightening (set F2), and the last is a set of post-thrusting faults (set F3) that formed in the same N-S compressional stress regime that activated the Guarga basement thrust.

2. The paleo-fluid system related to the fracture pattern is stratified and controlled by depositional environments during most of the history of vein mineral precipitation. The development of regional-scale foreland flexure and local-scale strata curvature-related vein sets triggered small-scale, interformational, vertical fluid migrations between Triassic and Paleocene reservoirs. The progressive switch from marine to continental paleo-environment occurring during Priabonian is recorded by a change of fluid source from local marine fluids to terrestrial surficial fluids.

3. Our interpretation of the fluid system in the Pico del Aguila anticline supports the hypothesis that fluid systems exhibit a common behavior during folding, wherein curvature-related joints facilitate vertical migration of fluids from one hydrostratigraphic reservoir to another. It also illustrates that the extent of such a vertical migration may be strongly reduced when folding affects poorly compacted sediments. Other similar case studies are needed to confirm if the fluid system evolution deciphered in the Pico del Aguila anticline is archetypal of fold-related fluid systems in shallow, syn-tectonic sedimentary settings. 


\section{Acknowledgments}

501 Authors thank N. Labourdette for analytical support and F. Delbas for thin-sections.

502 Authors are grateful to M. Fischer, M. Evans, and Editor W. Dunne for their inspiring and

503 highly helpful reviews, which have significantly improved this manuscript. S. Castelltort 504 is thanked for help in the field and fruitful discussions. This work was supported by 505 ISTeP and material support of LFC-R laboratory. 
References

Ahmadhadi, F., Daniel, J.M., Azzizadeh, M., Lacombe O., 2008. Evidence for pre-folding vein development in the Oligo-Miocene Asmari Formation in the Central Zagros Fold Belt, Iran. Tectonics 27, TC1016, doi:10.1029/2006TC001978

Anderson, E. M., 1951. The Dynamics of Faulting and Dyke Formation with Application to Britain. Oliver \& Boyd, Edinburgh.

Angelier, J., 1984, Tectonic analysis of fault slip data sets. Journal of Geophysical Research 89, 5835-5848.

Amrouch, K., Lacombe, O., Bellahsen, N., Daniel, J.-M., Callot, J.-P., 2010. Stress and strain patterns, kinematics and deformation mechanisms in a basement-cored anticline: Sheep Mountain Anticline, Wyoming. Tectonics 29, TC1005, 1-27, doi:10.1029/2009TC002525.

Anastasio, D.J., Holl, J.E., 2001. Transverse fold evolution in the External Sierra, southern Pyrenees, Spain. J. Struct. Geol. 23, 379-392.

Barbier, M., Leprêtre, R., Callot, J.-P., Gasparrini, M., Daniel, J.-M., Hamon, Y., Lacombe, O., Floquet, M., 2012a. Impact of fracture stratigraphy on the paleo-hydrogeology of the Madison Limestone in two basement-involved folds in the Bighorn basin, (Wyoming, USA). Tectonophysics, thematic issue : «Into the deformation history of folded rocks », O. Lacombe, S. Tavani, R. Soto (eds), 576-577, 116132.

Barbier, M., Hamon, Y., Callot, J.-P., Floquet, M., Daniel, J.-M., 2012b. Sedimentary and diagenetic controls on the multiscale fracturing pattern of a carbonate reservoir: The Madison Formation (Sheep Mountain, Wyoming, USA). Mar. Pet. Geol. 29, 50-67.

Beaudoin, N., Bellahsen, N., Lacombe, O., and Emmanuel, L., 2011. Fracture-controlled paleohydrogeology in a basement-cored, fault-related fold: Sheep Mountain Anticline, Wyoming, United States. Geochemistry Geophysics Geosystems 12, Q06011, doi: 10.1029/2010GC003494.

Beaudoin, N., Bellahsen, N., Lacombe, O., Emmanuel, L., Pironon, J., 2014. Crustal-scale fluid flow during the tectonic evolution of the Bighorn Basin (Wyoming, USA). Basin Research 26, 403-435.

Beaudoin, N., Lacombe, O., Bellahsen, N., Emmanuel, L., 2013. Contribution of Studies of Sub-Seismic Fracture Populations to Paleo-Hydrological Reconstructions (Bighorn Basin, USA). Procedia Earth Planet. Sci. 7, 57-60.

Beaudoin, N., Leprêtre, R., Bellahsen, N., Lacombe, O., Amrouch, K., Callot, J.-P., Emmanuel, L., Daniel, J.-M., 2012. Structural and microstructural evolution of the Rattlesnake Mountain Anticline (Wyoming, USA): new insights into the Sevier and Laramide orogenic stress build-ups in the BigHorn Basin. Tectonophysics, thematic issue : «Into the deformation history of folded rocks », O. Lacombe, S. Tavani, R. Soto (eds), 576-577, 20-45.

Bellahsen, N, Fiore, P., Pollard, D., 2006a. The role of fractures in the structural interpretation of Sheep Mountain Anticline, Wyoming. J. Struct. Geol. 28, 850-867. geomechanical approach. Geophysical Research Letters 33, L02301, doi:10.1029/2005GL024189. 
Bergbauer, S., Pollard, D.D., 2004. A new conceptual fold-fracture model including prefolding joints, based on the Emigrant Gap anticline, Wyoming. Geol. Soc. Am. Bull. 116, 294 - 307.

Billi, A., Salvini, F., 2003. Development of systematic joints in response to flexure-related fibre stress in flexed foreland plates: the Apulian forebulge case history, Italy. J. Geodyn. 36, 523-536.

Bodnar, R., 1993. Revised equation and table for determining the freezing point depression of H2O-Nacl solutions. Geochimica et Cosmochimica Acta 57, 683-684.

Boles, J. R., Eichhubl, P., Garven, G., Chen, J, 2004. Evolution of a hydrocarbon migration pathway along basin-bounding faults: Evidence from fault cement. AAPG Bull. 88, 947-970.

Bons, P., Elburg, M. A>, Gomez-Rivas, E., 2012. A review of the formation of tectonic veins and their microstructures. Journal of Structural Geology 43, 33-62.

Canudo, J.-I., Molina, E., Riveline, J., Serra-Kiel, J., Sucunza, M., 1988. Les évènements biostratigraphiques de la zone prépyrénéenne d'Aragon (Espagne), de l'Eocène Moyen à l'Oligocène Inférieur. Revue de Micropaléontologie 31, 15-29.

Castelltort, S., Guillocheau, F., Robin, C., Rouby, D., Nalpas, T., Lafont, F., Eschard, R., 2003. Fold control on the stratigraphic record: a quantified sequence stratigraphic study of the Pico del Aguila anticline in the south-western Pyrenees (Spain). Basin Research 15, 527-551.

Cooke, M., 1997. Predicting fracture localization in folded strata from mechanical stratigraphy and fold shape: Case study of east Kaibab Monocline, Utah. Int. J. Rock Mech. Min. Sci. 34, 56.

Cooper, S.P., Goodwin, L.B., Lorenz, J.C., 2006. Fracture and fault patterns associated with basement-cored anticlines: The example of Teapot Dome, Wyoming. Am. Assoc. Pet. Geol. Bull. 90, 1903-1920.

Durney, D.W., Ramsay, J.G., 1973. Incremental stramsmeasured by syntectomc crystal growths In Gravtty and Tectomcs (edited by De Jong, K A and Scholten. R ) John Wdey, New York, 67-96.

Evans, M. A., Bebout, G.E., Brown, C.H., 2012. Changing fluid conditions during folding: An example from the central Appalachians. Tectonophysics 576-577, 99-115.

Evans, M. A., Fischer, M.P., 2012. On the distribution of fluids in folds: A review of controlling factors and processes. J. Struct. Geol. 44, 2-24.

Evans, M., Battles, D., 1999. stable isotope analyses of veins from the central Appalachian Valley and Ridge province: Implications for regional synorogenic hydrologic structure and fluid migration. Geol. Soc. Am. Bull. 111, 1841-1860.

Ferket, H., Roure, F., Swennen, R., Ortuno, S., 2000. Fluid migration placed into the deformation history of fold-and-thrust belts: an example from the Veracruz basin (Mexico). Journal of Geochemical Exploration 69-70, 275-279.

Fischer, M.P., Higuera-Díaz, I.C., Evans, M. A., Perry, E.C., Lefticariu, L., 2009. Fracture-controlled paleohydrology in a map-scale detachment fold: Insights from the analysis of fluid inclusions in calcite and quartz veins. J. Struct. Geol. 31, 1490-1510.

Fischer, M.P., Jackson, P.B., 1999. Stratigraphic controls on eformation patterns in fault-related folds: a detachment fold example from the Sierra Madre Oriental, northeast Mexico. J. Struct. Geol. 21, 613633. pseudo - three-dimensional modeling and curvature analysis. Geology 28, 15-18. 
Fitz-Diaz, E., Hudleston, P., Siebenaller, L., Kirschner, D., Camprubí, A., Tolson, G., Puig, T.P., 2011. Insights into fluid flow and water-rock interaction during deformation of carbonate sequences in the Mexican fold-thrust belt. J. Struct. Geol. 33, 1237-1253.

Gale, J.F.W., Reed, R.M., Holder, J., 2007. Natural fractures in the Barnett Shale and their importance for hydraulic fracture treatments. Am. Assoc. Pet. Geol. Bull. 91, 603-622.

Hathaway, J. C., Degens, E.G., 1969. Methane-derived marine carbonates of Pleistocene age. Science 165, 690-692.

Hervouët, Y., Espurt, N., Dhont, D., 2005. Failles normales Paléocène à Lutétien en zone sud-pyrénéenne (Aragon, Espagne) et flexuration de la plaque ibérique. Comptes Rendus Geoscience 337, 385-392.

Henderson, I.H.C., McCaig, A. M., 1996. Fluid pressure and salinity variations in shear zone-related veins, central Pyrenees, France: Implications for the fault-valve model. Tectonophysics 262, 321-348.

Hilgers, C., Koehn, D., Bons, P.D., Urai, J.L., 2001. Development of crystal morphology during unitaxial growth in a progressively widening vein $\square$ : II . Numerical simulations of the evolution of antitaxial fibrous veins. Jou. Struc. Geol. 23, 873-885.

Hogan, P.J., Burbank, D.W., 1996. Evolution of the Jaca piggyback basin and emergence of the External Sierras, southern Pyrenees. In: P.F. Friend and C.J. Dabrio (Editors), Tertiary Basins of Spain. Cambridge Univ. Press, 153-160.

Huyghe, D., Mouthereau, F., Castelltort, S., Filleaudeau, P-Y., Emmanuel, L, 2009. Paleogene propagation of the southern Pyrenean thrust wedge revealed by finite strain analysis in frontal thrust sheets: implications for mountain building. Earth and Planetary Science Letters 288, 421-433.

Huyghe, D., Castelltort, S., Mouthereau, F., Serra-Kiel, J., Filleaudeau, P.-Y., Berthier, B., Emmanuel, L., Renard, M., 2012a. Large scale facies change in the middle Eocene South-Pyrenean foreland basin: The role of tectonics and prelude to Cenozoic ice-ages. Sedimentary Geology 253-254, 25-46.

Huyghe, D., Mouthereau, F., Emmanuel, L., 2012b. Oxygen isotopes of marine mollusc shells record Eocene elevation change in the Pyrenees. Earth and Planetary Science Letters 345-348, 131-141.

Jolivet, M., Labaume, P., Monie, P., Brunel, M., Arnaud, N., Campani, M., 2007. Thermochronology constraints for the propagation sequence of the south Pyrenean basement thrust system (FranceSpain), Tectonics 26, TC5007, doi:10.1029/2006TC002080.

Katz, D. A., Eberli, G.P., Swart, P.K., Smith, L.B., 2006. Tectonic-hydrothermal brecciation associated with calcite precipitation and permeability destruction in Mississippian carbonate reservoirs, Montana and Wyoming. Am. Assoc. Pet. Geol. Bull. 90, 1803-1841.

Kim, S.-T., O’Neil, J.R., 1997. Equilibrium and nonequilibrium oxygen isotope effects in synthetic carbonates. Geochim. Cosmochim. Acta 61, 3461-3475.

Lacombe 0., Swennen R., Caracausi A. (eds), 2014. Thematic Issue :Fluid-rock-tectonics interactions in basins and orogens. Marine and Petroleum Geology, 55, 1-332

Lacombe 0, Tavani S., Soto R. (eds), 2012. Thematic Issue : Into the deformation history of folded rocks. Tectonophysics, 576-577, 1-216

627 Lacombe O., 2012. Do fault slip data inversions actually yield 'paleostresses' that can be compared with contemporary stresses? A critical discussion. Comptes Rendus Geoscience 344, 159-173. 
Lacombe, O., Bellahsen, N., Mouthereau, F., 2011. Fracture patterns in the Zagros Simply Folded Belt (Fars, Iran): constraints on early collisional tectonic history and role of basement faults. Geological Magazine, thematic issue « Geodynamic evolution of the Zagros », O. Lacombe, B. Grasemann and G. Simpson (eds), 148, 940-963.

Lacroix, B., Buatier, M., Labaume, P., Travé, a., Dubois, M., Charpentier, D., Ventalon, S., Convert-Gaubier, D., 2011. Microtectonic and geochemical characterization of thrusting in a foreland basin: Example of the South-Pyrenean orogenic wedge (Spain). Journal of Structural Geology 33, 1359-1377.

Lacroix, B., Travé, A., Buatier, M., Labaume, P., Vennemann, T., Dubois, M., 2014. Syntectonic fluid-flow along thrust faults: Example of the South-Pyrenean fold-and-thrust belt. Marine and Petroleum Geology 49, 84-98.

Laubach, S.E., Olson, J., Gross, M.R., 2009. Mechanical and fracture stratigraphy. AAPG Bulletin 93, 14131427.

Machel, H.G., 2000. Application of Cathodoluminescence to carbonate diagenesis. In: Pagel, M., Barbin, V., Blanc, P., Ohnenstetter, D. (eds.), Cathodoluminescence in Geosciences. Springer-Verlag, Heigelberg, Germany, 271-302.

Machel, H.G., Cavel, P.A., 1999. Low-flux, tectonically-induced squeegee fluid flow (« hot flash ») into the Rocky Mountain Foreland Basin. Bulletin of Canadian Petroleum Geology 47, 510-533.

McCaig, A.M., Tritlla, J., and Banks, D., 2000, Fluid flow patterns during Pyrenean thrusting. Journal of Geochemical Exploration 69-70, 539-543.

McCaig, A.M., Wayne, D.M., Marshall, J.D., Banks, D., Henderson, I., 1995. Isotopic and fluid inclusion studies of fluid movement along the Gavarnie Thrust, central Pyrenees: reaction front in carbonate mylonites. American Journal of Science 295, 309-343.

Millán, H., 1996. Estructura y cinematica del frente de cabalgamiento surpirenaico, Sierras Exteriores aragonesas, PhD Thesis, Universidad de Zaragoza, Spain, 330 pp.

Millán, H., Aurell, M., Meléndez, A., 1994. Synchronous detachment folds and coeval sedimentation in the Prepyrenean External Sierras (Spain): a case study for a tectonic origin of sequences and systems tracts. Sedimentology 41, 1001-1024.

Molina, E., Ortiz, N., Serra-Kiel, J., 1988. Implicationes paleoecologicas de los foraminiferos en el Eocene del Prepirineo oscense (sector de Arguís). Revista Espanola de Paleontologia 3, 45-57.

Morley, C.K., Warren, J., Tingay, M., Boonyasaknanon, P., and Julapour, A., 2014, Comparison of modern fluid distribution, pressure and flow in sediments associated with anticlines growing in deepwater (Brunei) and continental environments (Iran): Marine and Petroleum Geology, thematic issue on fluid-rock-tectonics interactions in basins and orogens. , Lacombe O., Swennen R., Caracausi A. (eds), 55, 230-249, doi: 10.1016/j.marpetgeo.2013.11.011.

Nalpas, T., Gapais, D., Verges, J., Barrier, L., Gestain, V., Leroux, G., Rouby,D., Kermarrec, J.J., 2003. Effects of rate and nature of synkinematic sedimentation on the growth of compressive structures constrained by analogue models and field examples. Geol. Soc. Lond. Spec. Publ. 208, 307-319.

Novoa, E., Suppe, J., Shaw, J.H., 2000. Inclined-shear resto- ration of growth folds. AAPG Bull. 84, 787-804.

Oliva-Urcia, B., Pueyo, E., 2007. Rotational basement kinematics deducted from remagnetized cover rocks (Internal Sierras, southwestern Pyrenees). Tectonics 26, TC4014, doi:10.1029/2006TC001955. 
Poblet, J., Hardy, S., 1995. Reverse modelling of detachment folds; application to the Pico del Aguila anticline in the South Central Pyrenees (Spain). Journal of Structural Geology 17, 12, 1707 - 1724.

Poblet, J., Muñoz, J., Travé, A., and Sierra-Kiel, J., 1998. Quantifying the kinematics of detachment folds using three-dimensional geometry: Application to the Mediano anticline (Pyrenees, Spain). GSA Bulletin 110, 111-12.

Pueyo, E.L., Millán, H., Pocoví, A., 2002. Rotation velocity of a thrust: a paleomagnetic study in the External Sierras (Southern Pyrenees). Sedimentary Geology 146, 191-208.

Puigdefàbregas, C., 1975. La sedimentación molásica en la cuenca de Jaca. Pirineos 104, 1-188.

Pujalte, V., Baceta, J., Schmitz, B., Orue-Etxebarria, X., Payros, A., Bernaola, G., Apellaniz, E., Caballero, F., Robador, A., Serra-Kiel, J., Tosquella, J., 2009. Redefinition of the Ilerdian Stage (early Eocene ). Geologica Acta 7, 177-194.

Qing, H., Mountjoy, E., 1992. Large-scale fluid flow in the Middle Devonian Presqu'ile Barrier, Western Canada sedimentary basin. Geology 20, 903-906.

Quintà, A., Tavani, S., 2012. The foreland deformation in the south-western Basque-Cantabrian Belt (Spain).Tectonophysics, thematic issue : «Into the deformation history of folded rocks », 0. Lacombe, S. Tavani, R. Soto (eds), , 576-577, 4-19.

Ramsay, J., 1980. The crack-seal mechanism of rock deformation. Nature 284, 135-139.

Reynolds, T.J., Goldstein, R.H., 1994. Systematics of fluid inclusions in diagenetic minerals, SEPM Short Course.

Roedder, E., 1984. Fluid Inclusions. Rewiews in Mineralogy 12, 644 pp.

Rosenbaum, J., Sheppard, S.M.F., 1986. An isotopic study of side- rites, dolomites and ankerites at high temperatures. Geochimica et Cosmochimica Acta 50, 1147-1150.

Roure, F., Swennen, R., Schneider, F., Faure, J.L., Ferket, H., Guilhaumou, N., Osadetz, K., Robion, P., Vandeginste, V., 2005. Incidence and Importance of Tectonics and Natural Fluid Migration on Reservoir Evolution in Foreland Fold-And-Thrust Belts. Oil Gas Sci. Technol. 60, 67-106.

Savage, H.M., Ryan Shackleton, J., Cooke, M.L., Riedel, J.J., 2010. Insights into fold growth using fold-related joint patterns and mechanical stratigraphy. J. Struct. Geol. 32, 1466-1475.

Sztràkos, K., Castelltort, S., 2001. La sédimentologie et les foraminifères bartoniens et priaboniens des coupes d'Arguis (Prépyrénées aragonaises, Espagne). Incidence sur la corrélation des biozones à la limite Bartonien/Priabonien. Revue de Micropaléontologie 44, 233-247.

Tavani, S., Storti, F., Fernández, O., Muñoz, J. a., Salvini, F., 2006. 3-D deformation pattern analysis and evolution of the Añisclo anticline, southern Pyrenees. J. Struct. Geol. 28, 695-712.

Teixell, A., 1996. The Anso transect of the southern Pyrenees: basement and cover thrust geometries. Journal of the Geological Society. 153, 301-310.

Travé, A., Calvet, F., Sans, M., Verges, J., and Thirlwall, M., 2000. Fluid history related to the Alpine compression at the margin of the south-Pyrenean Foreland basin: the El Guix anticline. Tectonophysics, 321, 73-102.

Travé, A., Labaume, P., and Vergés, J., 2007, Fluid systems in Foreland Fold-and-Thrust Belts: An overview from the Southern Pyrenees. In: Lacombe, O., Lavé, J., Roure, F., and Vergés, J. eds,, Thrust Belts and Foreland Basins : From Fold Kinematics to Hydrocarbons Systems, Springer, 93-115. 
Van Geet, M., Swennen, R., Durmishi, C., Roure, F., Muchez, P.H., 2002. Paragenesis of Cretaceous to Eocene carbonate reservoirs in the Ionian fold and thrust belt (Albania): relation between tectonism and fluid flow. Sedimentology 49, 697-718.

Vandeginste, V., Swennen, R., Allaeys, M., Ellam, R.M., Osadetz, K., Roure, F., 2012. Challenges of structural diagenesis in foreland fold-and-thrust belts: A case study on paleofluid flow in the Canadian Rocky Mountains West of Calgary. Mar. Pet. Geol. 35, 235-251.

Vidal-Royo, O., Koyi, H. A., Muñoz, J.A., 2009. Formation of orogen-perpendicular thrusts due to mechanical contrasts in the basal décollement in the Central External Sierras (Southern Pyrenees, Spain). Journal of Structural Geology 31, 523-539.

Vidal-Royo, O., Cardozo, N., Muñoz, J.A.; Hardy, S., Maerten, L., 2012. Multiple mechanisms driving detachment folding as deduced from 3D reconstruction and geomechanical restoration: the Pico del Aguila anticline (External Sierras, Southern Pyrenees). Basin Research 24, 294-313.

Vidal-Royo, O., Munoz, J.A., Hardy, S., Koyi, H., Cardozo, N., 2013. Structural evolution of the Pico del Águila anticline (external Sierras, southern Pyrenees) derived from sandbox, numerical and 3D structural modelling Techniques. Geologica Acta 11, 1-26.

Zamarreño, I., Anadón, P., Utrilla, R., 1997. Sedimentology and isotopic composition of Upper Palaeocene to Eocene non-marine stromatolites, eastern Ebro Basin, NE Spain. Sedimentology 44, 159-176. 
Captions

730 Figure 1: A- Regional geological map of the Southern Central Pyrenees with location of

731 the balanced cross-sections that cross the Pico del Aguila anticline (Huyghe et al., 2009);

732 B- Stratigraphic column for the Pico del Aguila area (after Castelltort et al., 2003).

733 Lithological key of patterns from bottom to top: carets - evaporate, dashs - clay,

734 parallelograms - dolostone, rectangles - limestone, big dots in irregular shapes - river

735 conglomerates, plain black - marls, fine dots - sandstone; C- Transverse and longitudinal

736 regional cross-sections in the Sierras Exteriores, focusing on the Pico del Aguila Area

737 (Huyghe et al., 2009).

738

739 Figure 2: Geological map of the Pico del Aguila Anticline based on previously published maps (Puigdefabregas, 1975; Millán, 1996; Vidal-Royo et al., 2012), aerial photographs and new field observation and measurements. A balanced cross-section following line C-

742 C' is presented, with a length balance of layers for strata younger than Triassic and an 743 area balance for the Triassic rocks of the décollement. Dotted frames on the maps are 744 areas of maps presented in figures 4-6. White-labeled black dots locate fracture measurement sites or sample sites for geochemical analyses. Please refer to supplementary material 2 for GPS values. In the stratigraphy caption box, "cont." refers

747 to continental environment.

749 Figure 3: Photomicrographs of thin- and thick-sections using polarized and crosspolaryzed microscopy. a - Multiple crack-seals and fibrous vein where calcite crystals exhibit the growth direction, recording a mixed mode I-mode II 'transtensional' opening mode of the vein (sample A14); b - Vein with elongated blocky calcite texture where the grain growth direction is perpendicular to the border of the vein, indicating a mode I opening (sample A44). c - Photomicrograph of fluid inclusions in a thick-section. Biggest primary or pseudo-secondary fluid inclusions are circled in red and the stained parts in crystals corresponds to an increase in density of secondary fluid inclusion trails (sample A45). $d$ - Calcite vein with blocky texture fringed by microsparitic crystals, recording a two-stage opening of the vein (sample A86), analogous to the crack-seal model (Ramsay, 1980). 
761 Figure 4: Results of fracture analysis in the Triassic to Lutetian prefolding strata in the

762 anticline. Results are presented on 3 diagrams (Schmidt' lower-hemisphere, equal-area

763 stereonets) displaying raw data in current strata attitude (left), then corrected for fold

764 axial plunge related to the Gavarnie thrust activation (middle), and corrected for local

765 bedding dip (right). Location of the measurement area is given in Fig. 2 and in

766 supplementary material 2. Abbreviations on the map are for the formations: Ar - Arguis

767 Fm., Gu - Guara Fm., Tp - Tremp Fm., A-B - Adraen Bona Fm., Tr - Triassic Fms.

768

769 Figure 5: Results of fracture analysis in the western syncline located in the Pico del 770 Aguila area. Same key as in Fig. 4. Abbreviations on the map are for formations: Ar 771 Arguis Fm., Gu - Guara Fm., Tp - Tremp Fm., A-B - Adraen Bona Fm.

Figure 6: Results of fracture analysis in the syn-folding and post-folding strata of Bartonian to Priabonian age, respectively. Same key as in Fig. 4. Abbreviations on the map are for formations: Cp - Campodarbe Fm., B-A - Beslusé Atares Fm., Ar - Arguis

776 Fm., Gu - Guara Fm.

Figure 7: Results of fault-slip inversion (Schmidt' stereonets lower hemisphere). Computed stress axes are reported as stars with three branches $\left(\sigma_{1}\right)$, four branches $\left(\sigma_{2}\right)$ and five branches $\left(\sigma_{3}\right)$. Convergent/divergent black arrows indicate the direction of compression/tension. Results are represented in the current attitude of strata, and diagrams labeled as "corrected" correspond to the same computed tensor and fault-slip data but corrected for removal of fold axial plunge related to the activation of Gavarnie thrust. Diagrams labeled as "unbasc" are corrected for fold axis plunge then for bed tilt. Diagrams are gathered according to consistency of reconstructed paleostress tensors. Abbreviations on the map are for formations: Cp - Campodarbe Fm., B-A - Belsué Atares Fm., Ar - Arguis Fm., Gu - Guara Fm., Tp - Tremp Fm., A-B - Adraen Bona Fm., Tr Triassic Fms.

Figure 8: a-d - Field photographs with chronological interpretations of fracture 791 networks. Sites for photographs: site 39(a), site 497 (b), site 476 (c), and site 447(d). e-f 792 - Photographs of faults and fractures showing the spacing and vertical persistence of 793 fractures observed at site 433 (refer to Figs. 4 to 7 for location). 
795 Figure 9: Photomicrographs of thin sections under cathodoluminescence microscopy: a

796 - Heterogeneous blocky-type calcite in vein, with brightness variation related to crystal 797 boundaries or to atomic-scale defects (sample A77); b - Heterogeneous blocky-type 798 calcite in vein exhibiting bright to dull orange zonation related to crystal growth (sample 799 A37); c - Elongated blocky-type calcite in vein exhibiting brightness variation related to 800 crystals (sample A44, Fig. 3-b). Please refer to the electronic version for colors.

801

802 Figure 10: Results of $\delta^{18} \mathrm{O}$ and $\delta^{13} \mathrm{C}$ analysis of veins and host-rocks displayed in context 803 of fracture age with respect to folding. a - $\delta^{18} 0$ vs $\delta^{13} \mathrm{C}$ plot, b $-\delta^{18} 0$ of veins vs $\delta^{18} 0$ of 804 related host-rocks. On all charts, solid symbols are for vein cements and fault coatings, 805 whereas empty symbol are for related host-rocks samples. Please refer to the text for 806 the explanation of labels (1) to (4). All values are expressed in \%oPDB. Labels XX/YY 807 refers to the number of analyzes performed / number of samples collected. See Table 2 808 and Supplementary Table S1 for detailed isotopic data.

810 Figure 11: Schematic block diagrams of structural, sedimentary and mesostructural 811 evolutionary scenario of the Pico del Aguila anticline. Fracture sets and related 812 contractional/extensional trends are illustrated. Stratigraphic timing and timing with 813 respect to folding stated for each block diagram. Fractures are not represented 814 according to abundance. Labels (1) to (5) are related to local and regional stress 815 orientations (see text).

817 Figure 12: a - Schematic cross-section illustrating evolution of the paleo-fluid system in 818 the Pico del Aiguila Anticline. b - Comparison with the Sheep Mountain anticline, 819 Wyoming, USA (after Beaudoin et al., 2011; Evans and Fischer, 2012).

821 Table 1: Results of the statistical interpretation of fracture set orientation, stratigraphic 822 distribution and indicators for relative chronology.

824 Table 2: Number of samples used for isotopic analysis in each formation, along with the related range of isotopic values measured. 
826

827 Table S1: Results of isotopic analyses.

828 Table S2: Geographical location of samples and measurement sites

829 


\begin{tabular}{ccccc} 
Set name & Set strike* & Set inclination & Stratigraphic units & Evidence for relative age \\
\hline \hline $\mathrm{J} 1$ & 120 & bed-normal & Guara - lower Arguis & RD, CC, A \\
$\mathrm{J} 2$ & 90 & bed-normal & Guara & RD, CC, A \\
$\mathrm{J} 3$ & 70 & bed-normal & All & $\mathrm{CC}, \mathrm{A}$ \\
$\mathrm{J} 4$ & 40 & bed-normal & All & $\mathrm{CC}, \mathrm{A}$ \\
$\mathrm{J} 5$ & 170 & sub bed-normal & All & $\mathrm{CC}, \mathrm{A}$ \\
\hline *: mean strike within 10 & & \\
RD: Restricted to Stratigraphic units CC: cross-cutting relationships; A: respect andersonian criterion \\
\hline \hline
\end{tabular}




\section{ACCEPTED MANUSCRIPT}

\begin{tabular}{|c|c|c|c|c|c|}
\hline \multirow{2}{*}{$\begin{array}{l}\text { Age relative } \\
\text { to folding }\end{array}$} & \multicolumn{2}{|c|}{ Formation } & \multirow{2}{*}{$\begin{array}{c}\text { number of analyses/number } \\
\text { of samples }\end{array}$} & \multicolumn{2}{|c|}{ Range of isotopic values (> $80 \%$ samples) } \\
\hline & & & & $\delta^{18} \mathrm{O}(\% \circ \mathrm{PDB})$ & $\delta^{13} \mathrm{C}(\% \circ \mathrm{PDB})$ \\
\hline \multirow{2}{*}{ Post-folding } & \multirow{2}{*}{ Campodarbe } & veins & $7 / 8$ & -2.20 to -0.02 & -1.77 to -0.77 \\
\hline & & host-rock & $7 / 8$ & -6.05 to -5.4 & -1.2 to 0.05 \\
\hline \multirow{6}{*}{ Syn-folding } & Belsue & veins & $2 / 3$ & -4.65 to -2.91 & -2.61 to -1.38 \\
\hline & Atares & host-rock & $3 / 3$ & -5.81 to -4.81 & -1.53 to 0.11 \\
\hline & \multirow{2}{*}{ Arguis } & veins & $25 / 25$ & -4.35 to -0.66 & -1.64 to 0.48 \\
\hline & & host-rock & $20 / 25$ & -4.47 to -2.55 & -1.7 to 0.43 \\
\hline & \multirow{2}{*}{ Guara } & veins & $29 / 29$ & -10.4 to -1.42 & -0.05 to 2.25 \\
\hline & & host-rock & $20 / 29$ & -6.7 to -1.42 & -1.5 to 2.15 \\
\hline \multirow{6}{*}{ Pre-folding } & \multirow{2}{*}{ Tremp } & veins & $3 / 3$ & -7.26 to -6.71 & -7.77 to -6.34 \\
\hline & & host-rock & $1 / 3$ & -3.77 & -6.29 \\
\hline & \multirow[b]{2}{*}{ Adraen Bona } & veins & $1 / 1$ & -5.43 & -0.56 \\
\hline & & host-rock & $1 / 1$ & -3.9 & 1.49 \\
\hline & \multirow{2}{*}{ Triassic } & veins & $3 / 4$ & -7.65 to -6.73 & -5.43 to -3.51 \\
\hline & & host-rock & $4 / 4$ & -5.78 to -3.28 & -1.37 to 2.65 \\
\hline
\end{tabular}



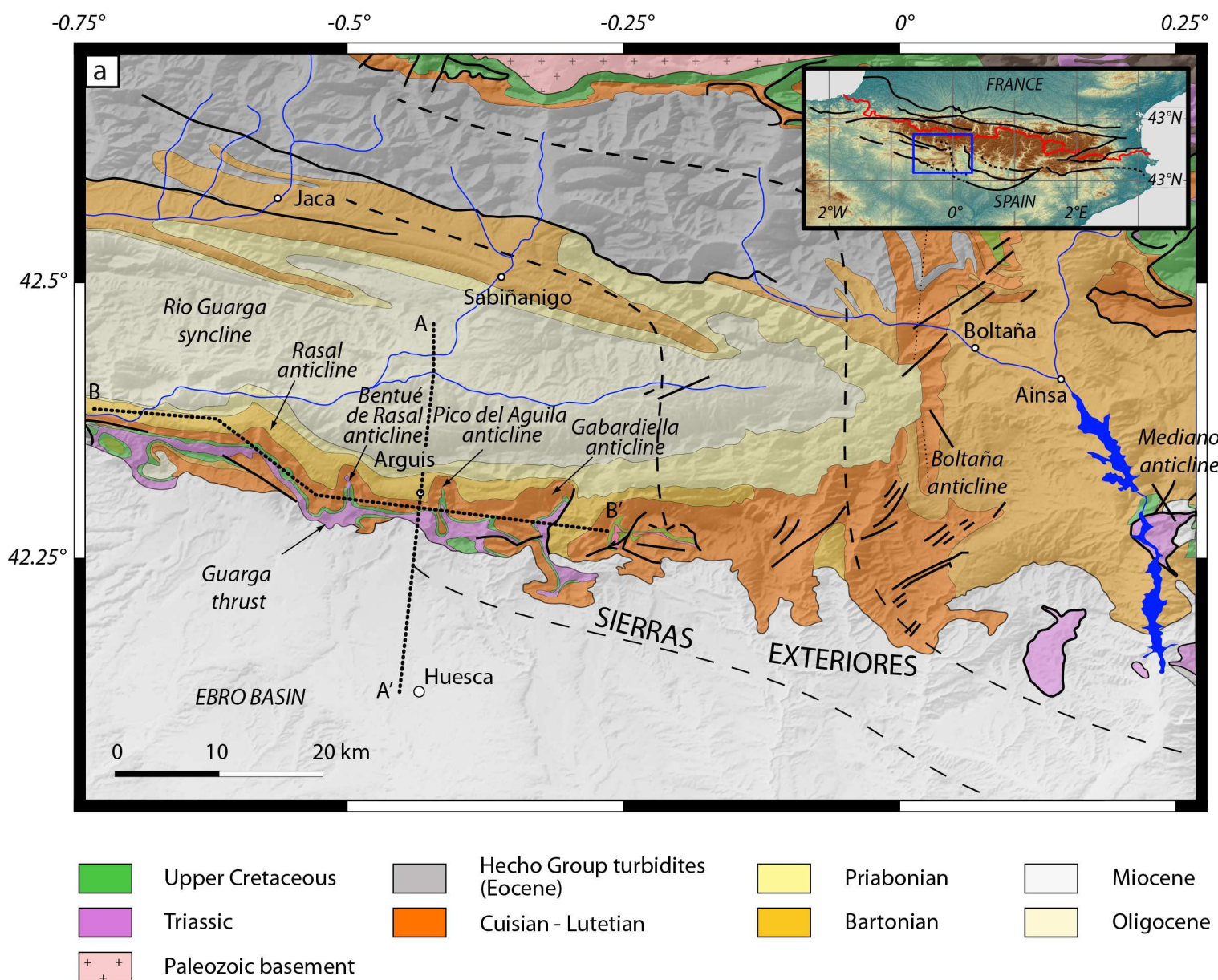

$A^{\prime}$

A Cross section

- Faults

_ _ _ Buried Faults

Fold axis

b

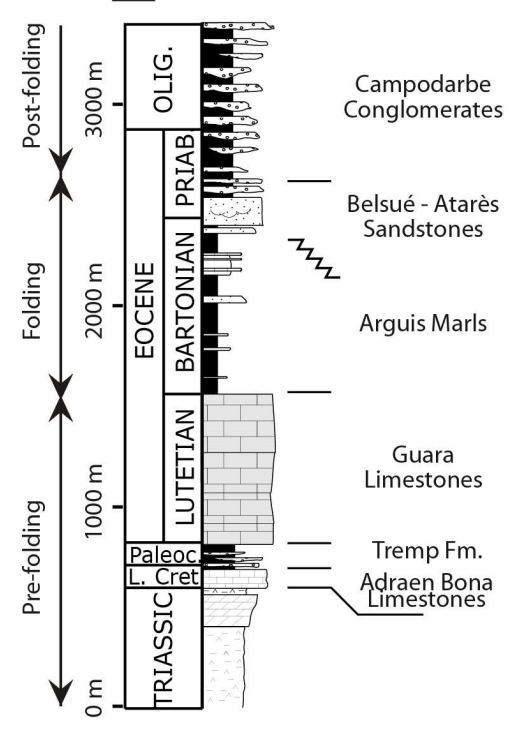

B B'

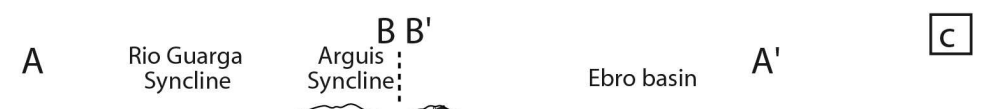

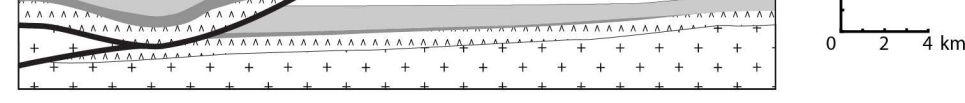

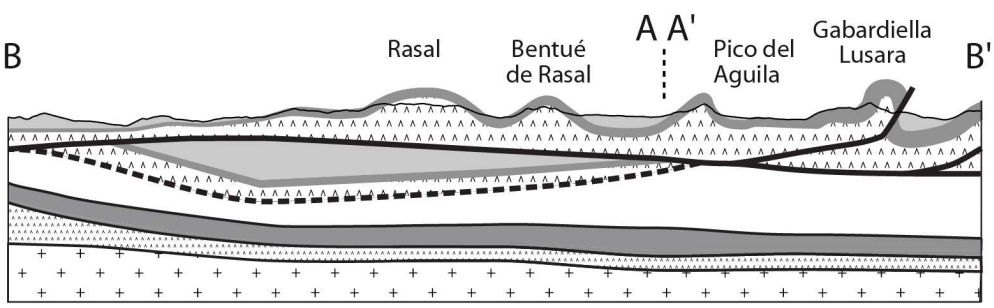

\begin{tabular}{ll}
\multicolumn{1}{c}{ Upper Cretaceous - } \\
Lower Paleocene and
\end{tabular} Triassic detachment unit

Bartonian

Guara Limestone Fm Cuisian - Lutetian

Alveolina Limestone Fm (Lower Eocene)

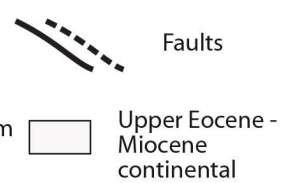




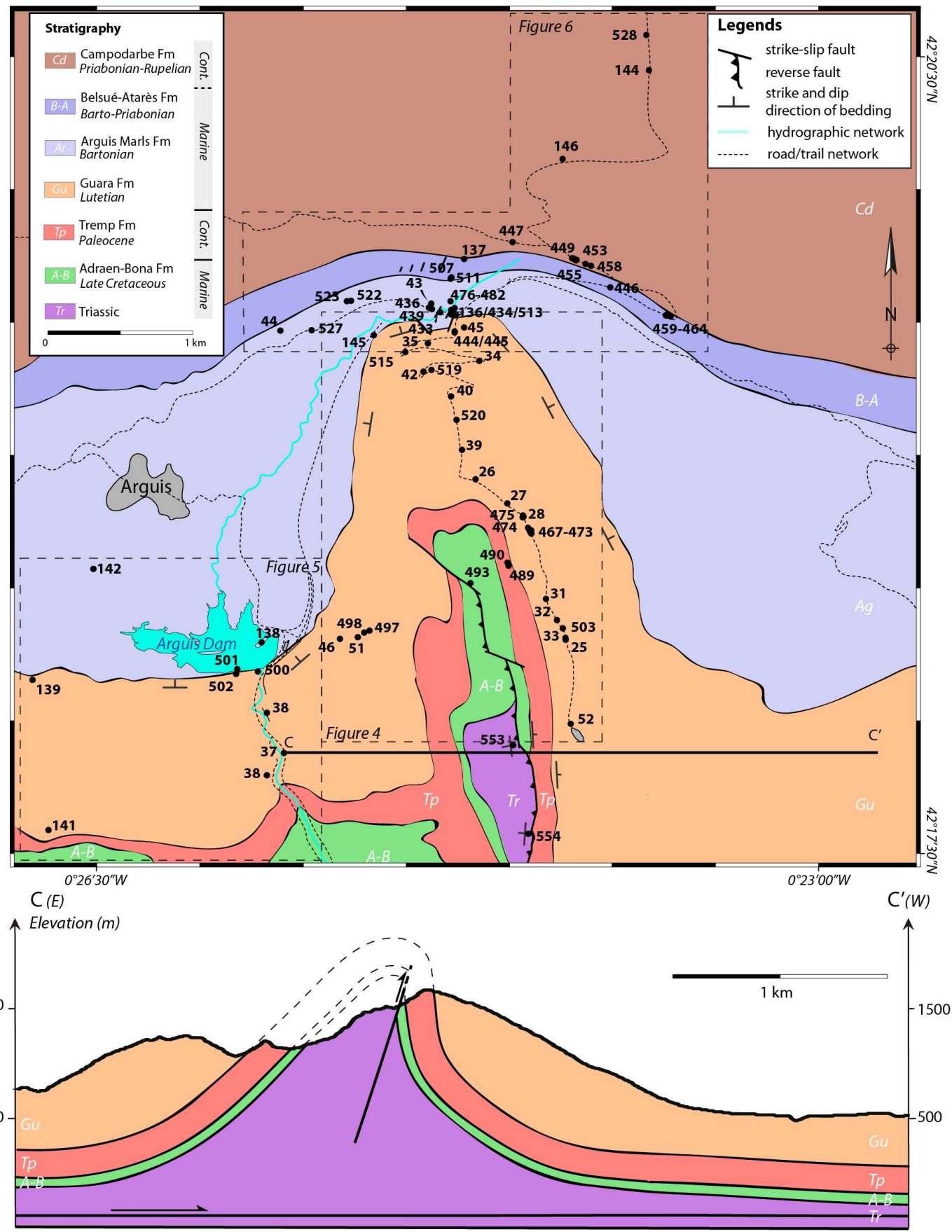



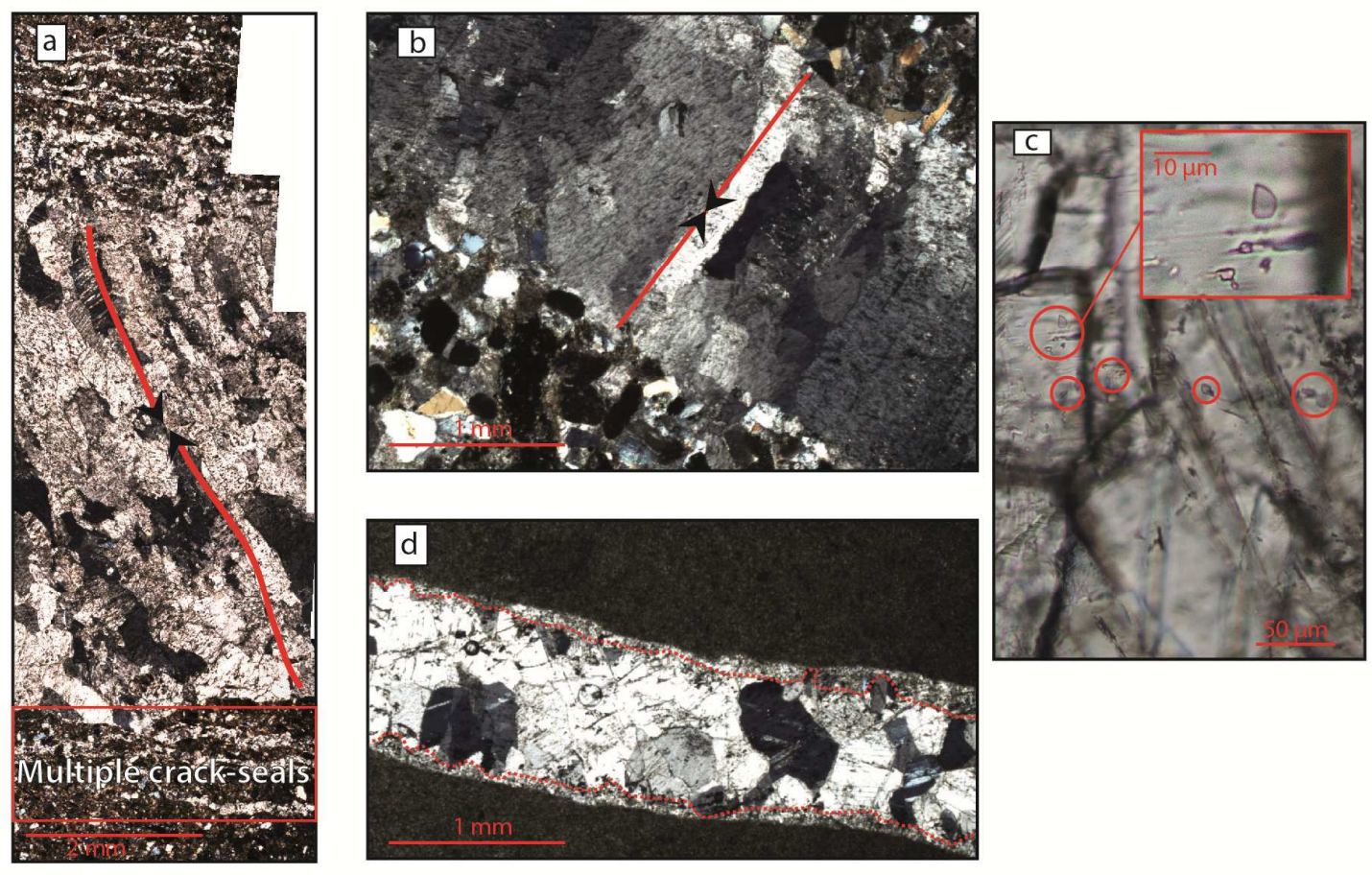


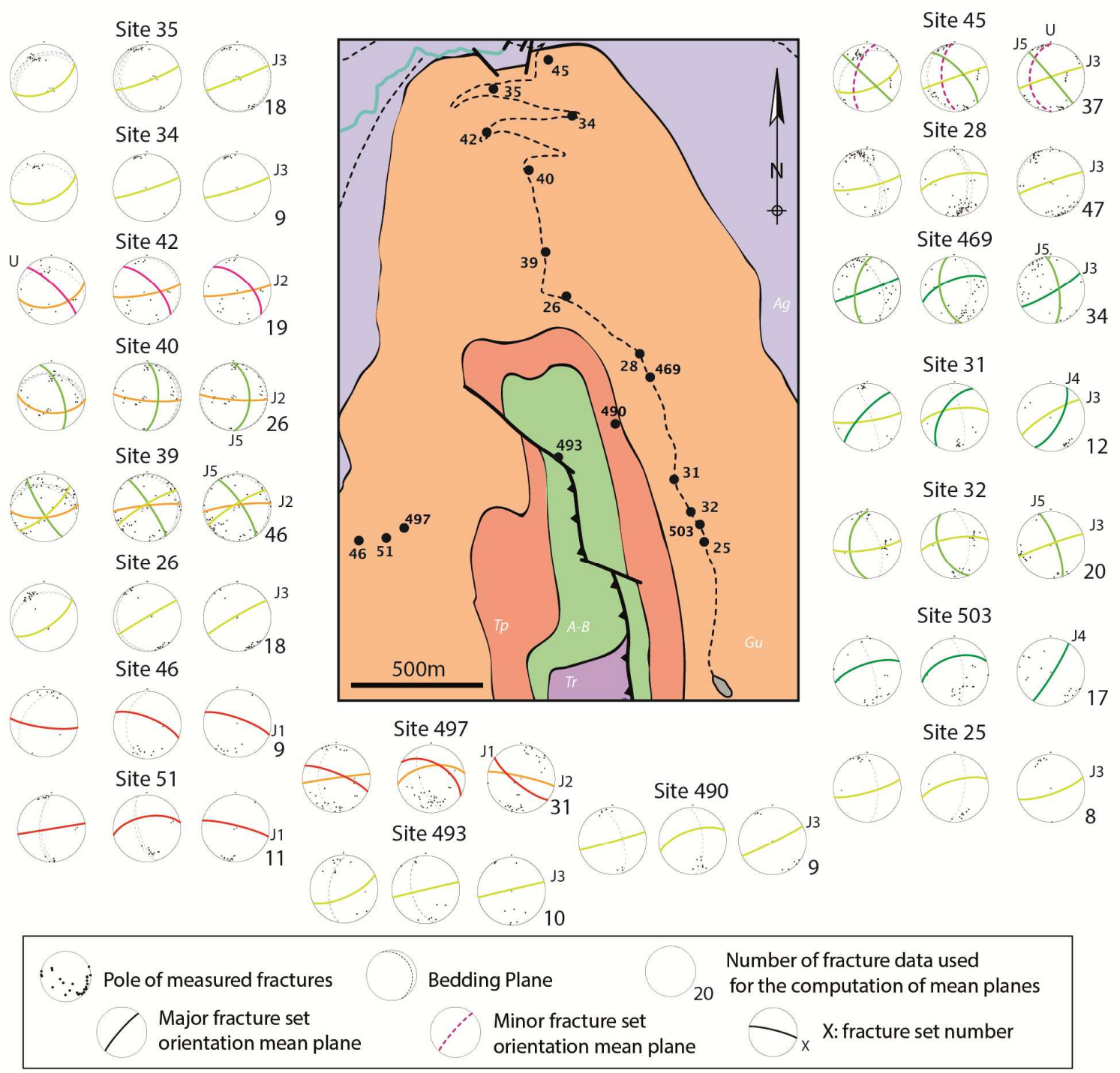




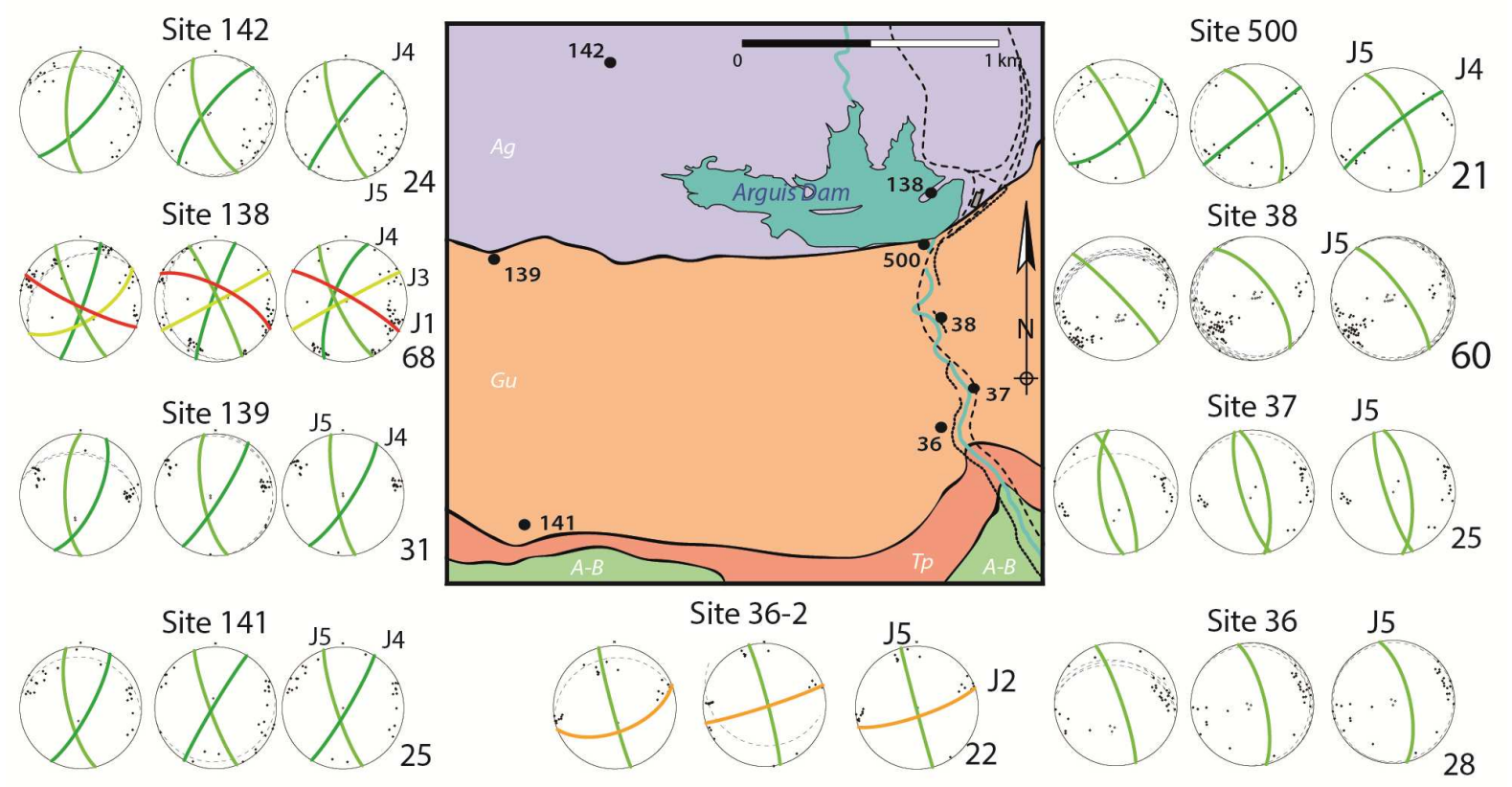




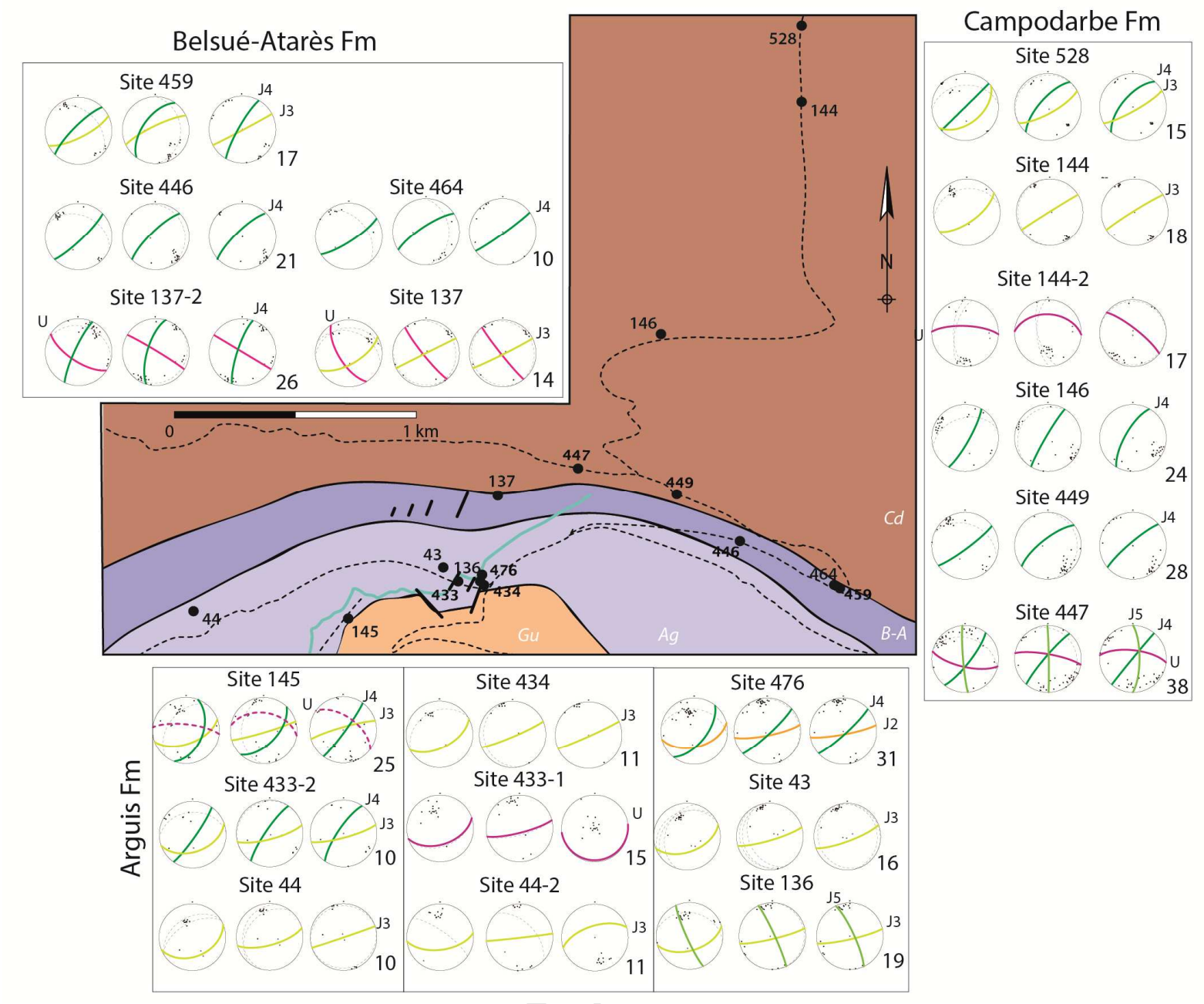



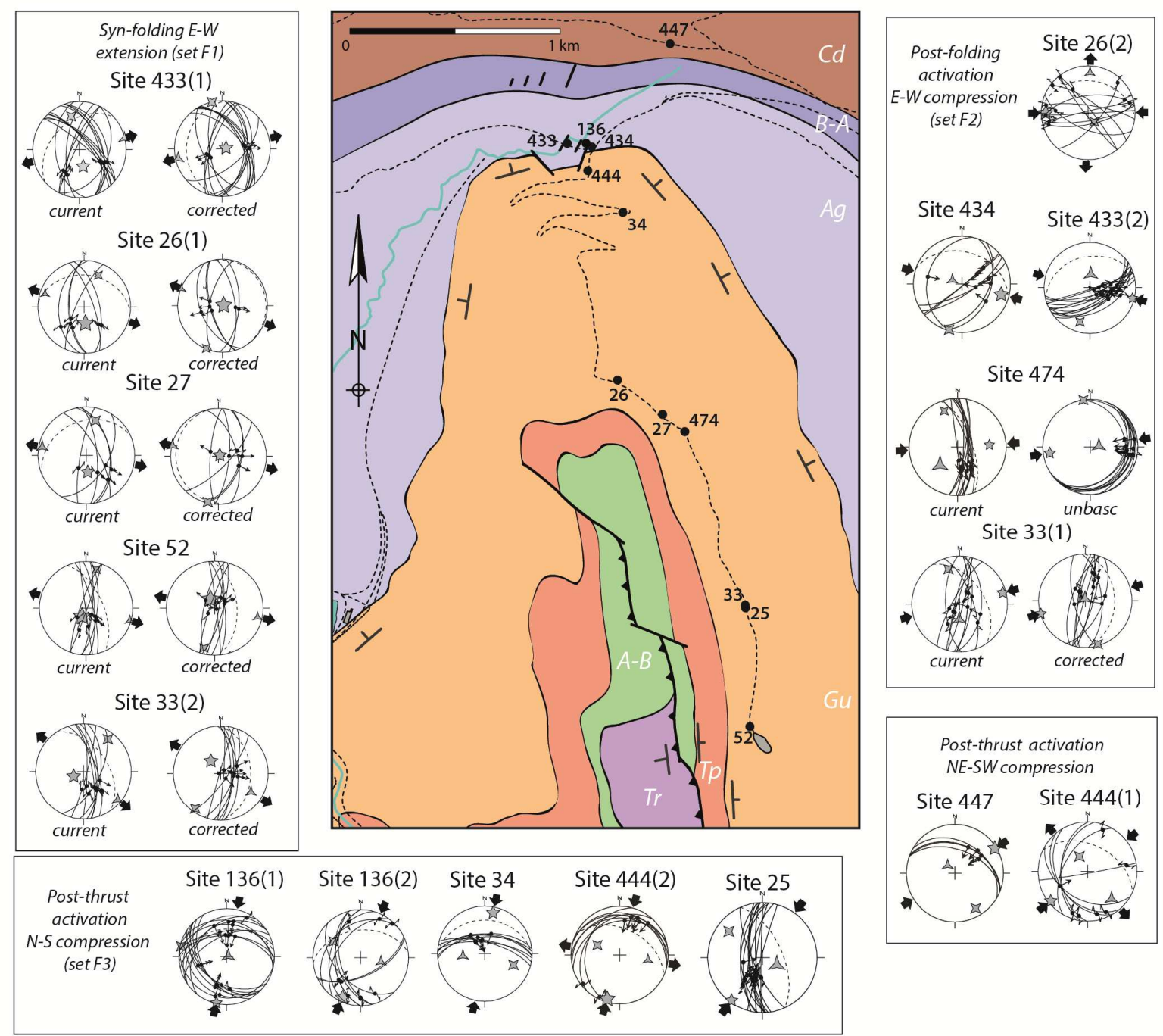

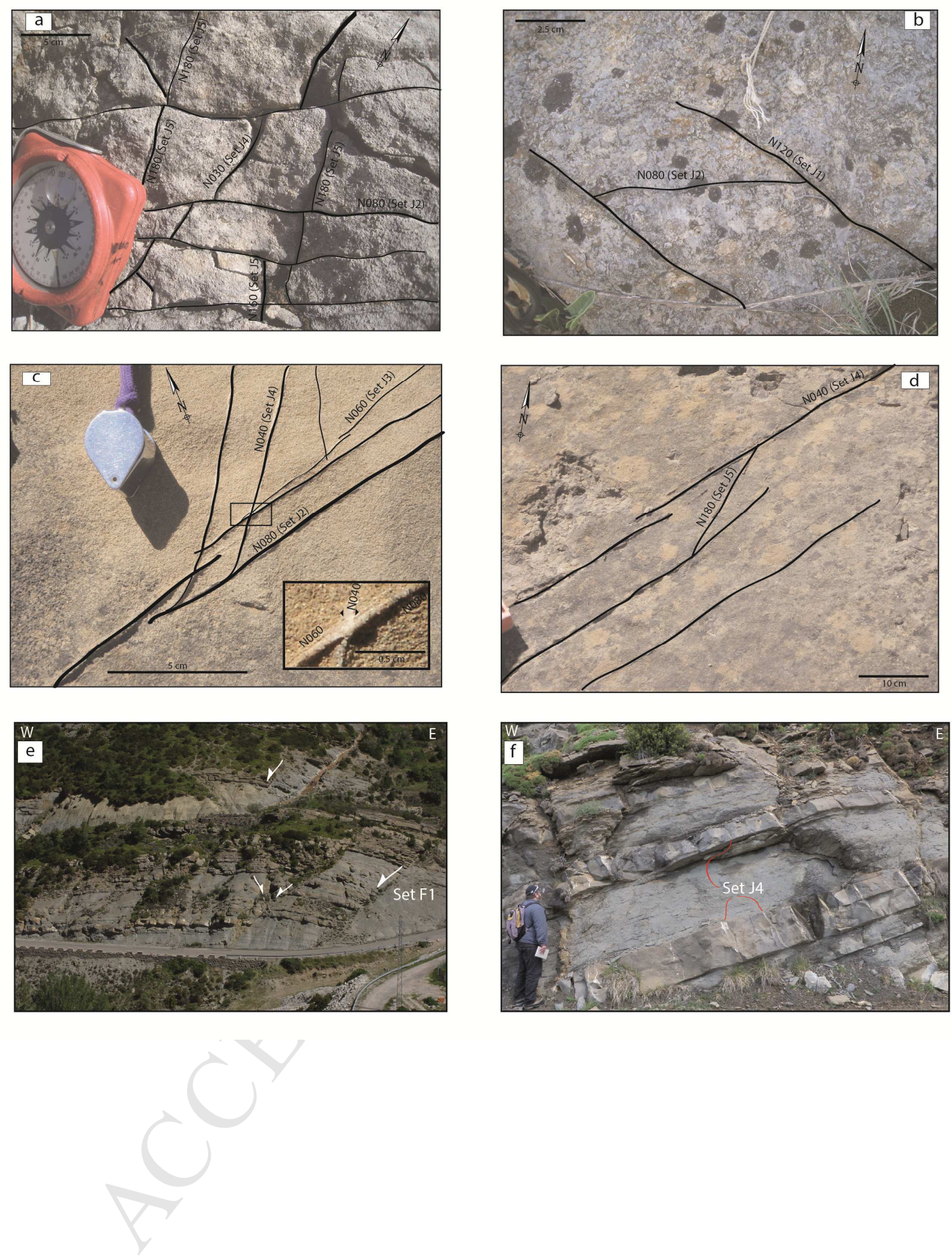

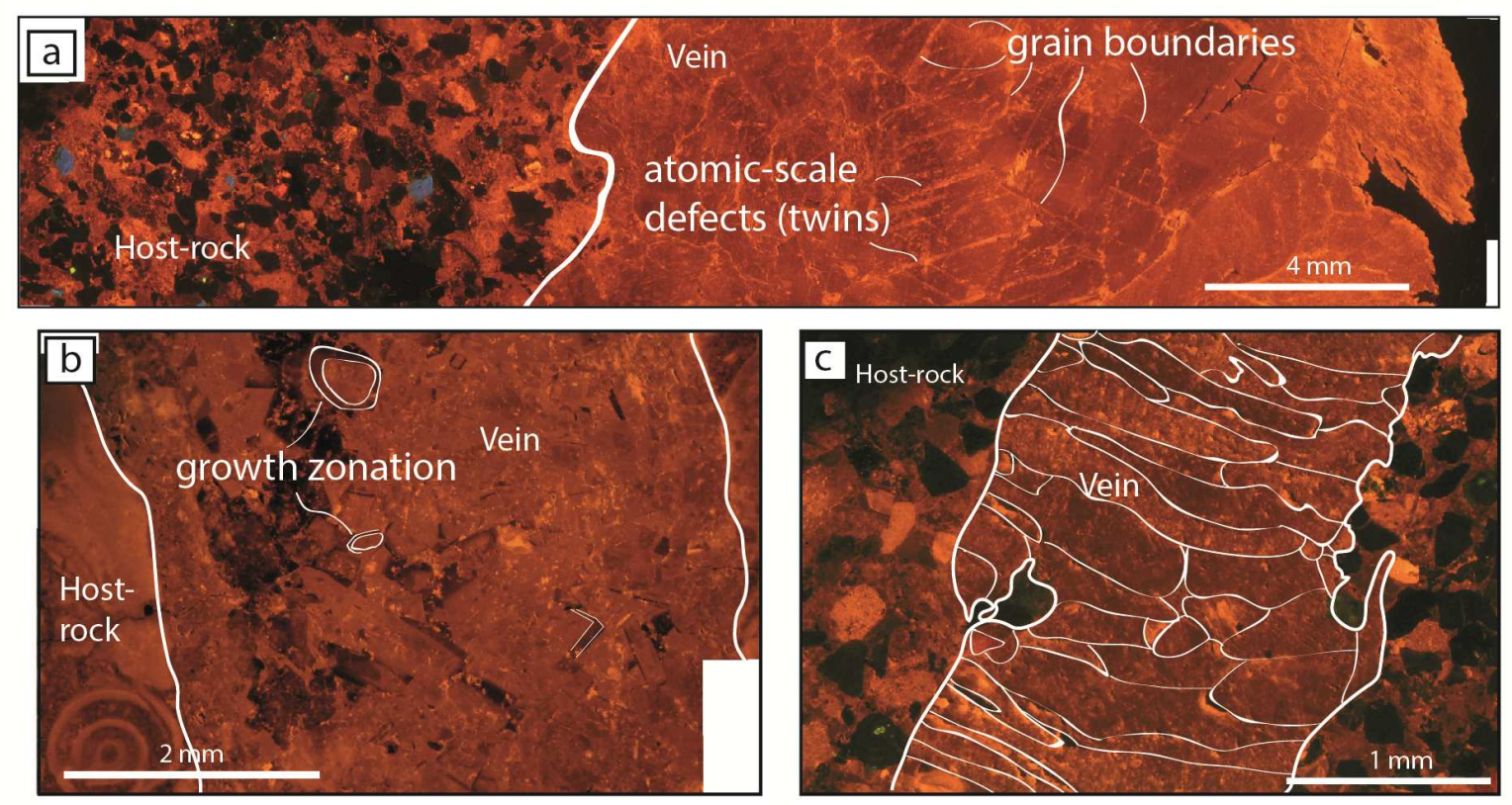

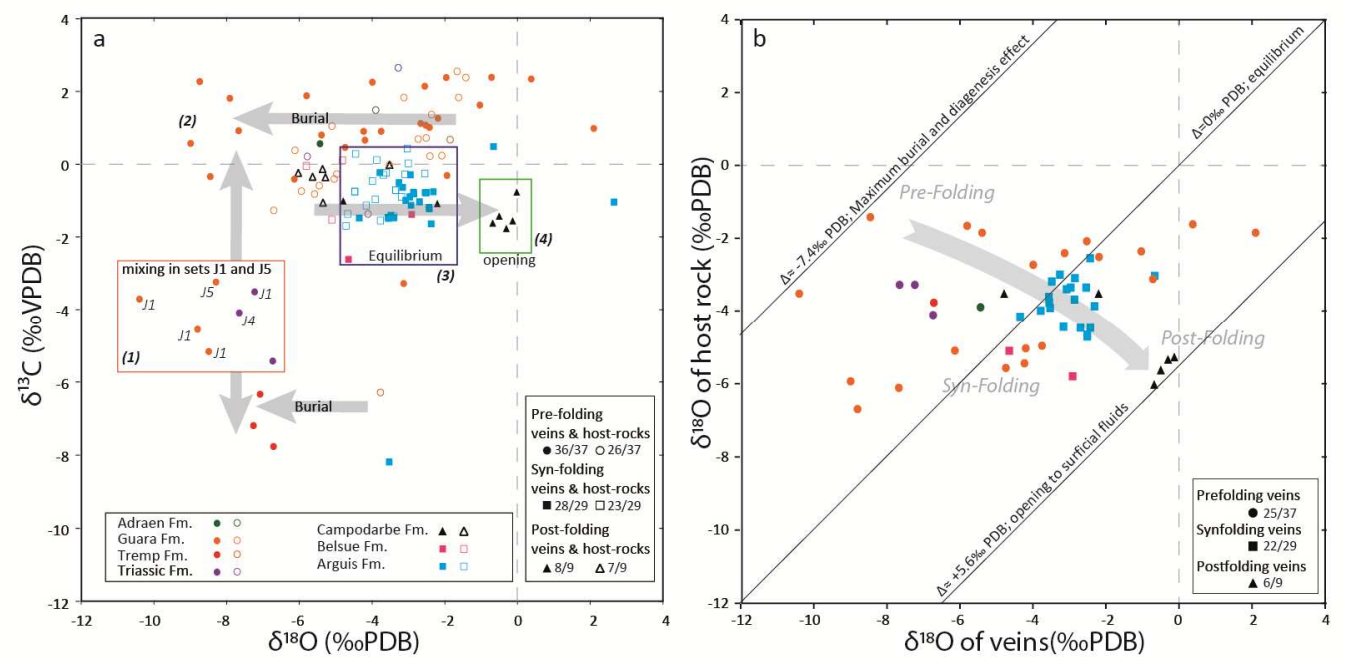

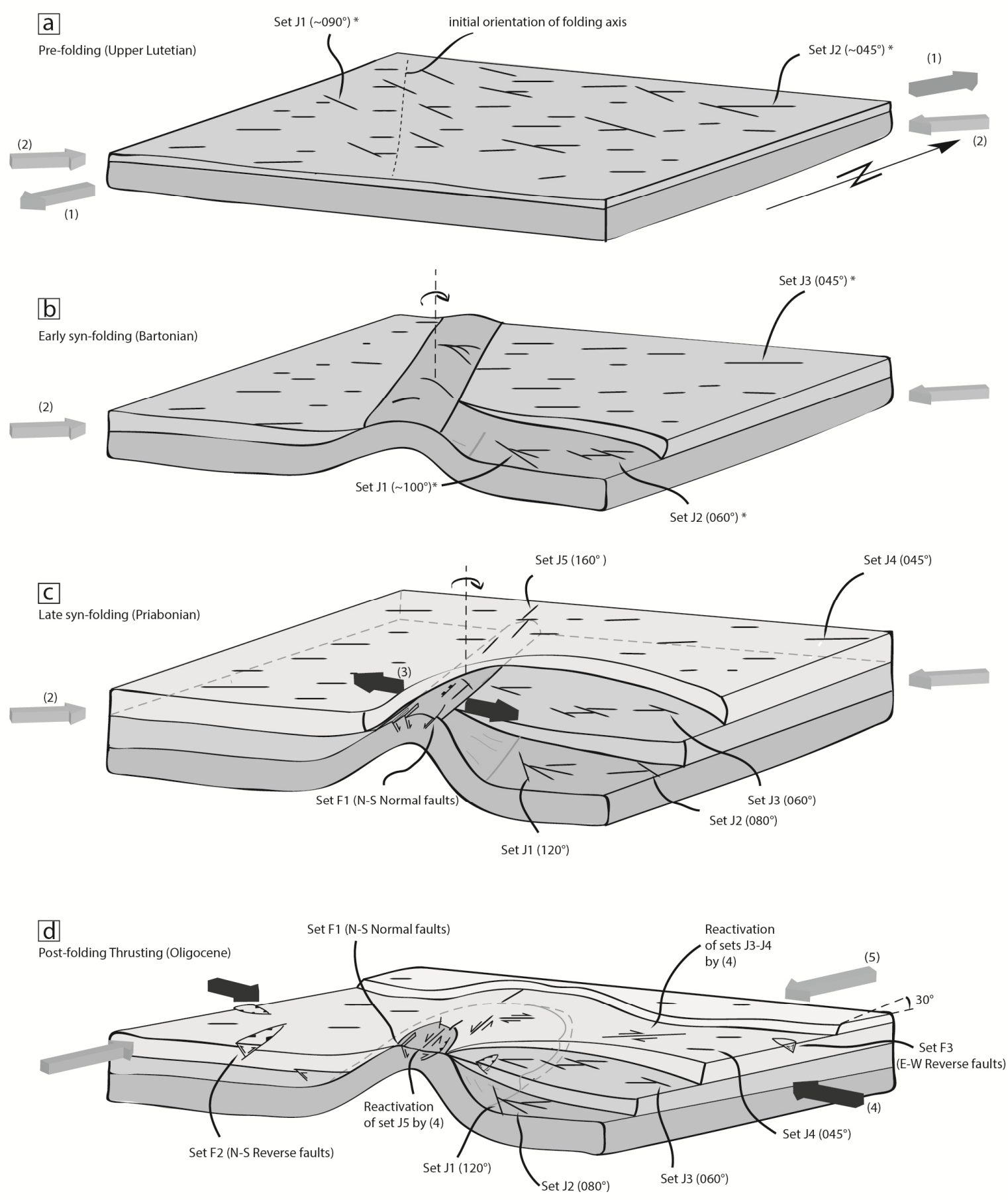


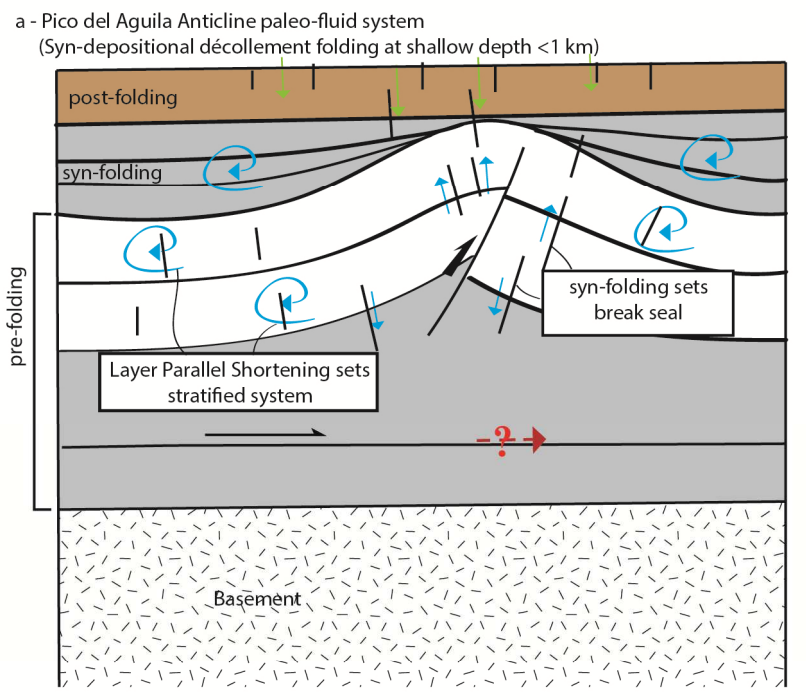

b - Sheep Mountain Anticline paleo-fluid system (Beaudoin et al., 2011) (Post-compaction basement-cored folding at depth $>2 \mathrm{~km}$ )

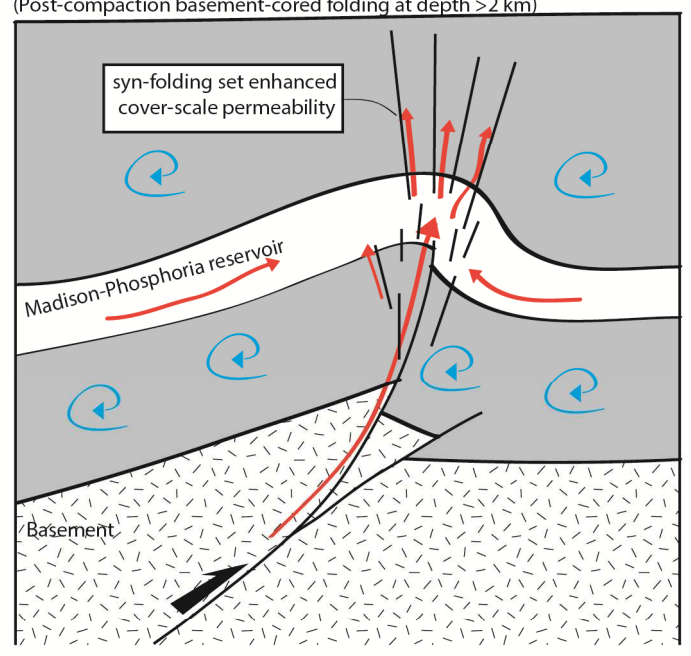

fluid system -arrows for direction of migration-


Highlights:

. Fluid system deciphered during syn-sedimentary folding

. Role of tectonic and sedimentary environment on fluid system evolution

. Role of burial on vertical permeability of fractures

. Fracture development witnesses fold rotation around a vertical axis 


\begin{tabular}{|c|c|c|c|c|c|c|c|c|c|}
\hline \multirow{2}{*}{$\begin{array}{c}\text { Deposition } \\
\text { regarding folding }\end{array}$} & \multirow[t]{2}{*}{ Sample } & \multirow[t]{2}{*}{ Formation } & \multirow[t]{2}{*}{ Age } & \multirow[t]{2}{*}{ Fracture Set } & \multicolumn{2}{|c|}{ Vein isotopic ratios } & \multicolumn{2}{|c|}{ Host rock isotopic ratio } & Site Number \\
\hline & & & & & $\partial^{18} \mathrm{O}$ & $\partial^{13} \mathrm{C}$ & $\partial^{18} 0$ & $\partial^{13} \mathrm{C}$ & (Figure for location) \\
\hline & A040 & Campodarbe & Priabonian & Set J4 & & & -5.36 & -0.13 & 4447 (Fig. 6) \\
\hline & A041 & Campodarbe & Priabonian & Set J5 & -0.3 & -1.77 & -5.35 & -1.06 & 449 (Fig. 6) \\
\hline & $\mathrm{A} 042$ & Campodarbe & Priabonian & Set J5 & -0.68 & -1.62 & -6.03 & -0.24 & 450 (Fig. 6) \\
\hline dain & $\mathrm{A} 044$ & Campodarbe & Priabonian & Set J4 & -0.13 & -1.56 & -5.28 & -0.36 & 452 (Fig. 6) \\
\hline & A045 & Campodarbe & Priabonian & Set J4 & -0.5 & -1.43 & -5.64 & -0.34 & 453 (Fig. 6) \\
\hline & $\mathrm{A} 048$ & Campodarbe & Priabonian & Set J3 & -0.02 & -0.77 & & & 455 (Fig. 6) \\
\hline & A050 & Campodarbe & Priabonian & Set J4 & -2.2 & -1.08 & -3.52 & -0.02 & 458 (Fig. 6) \\
\hline & $\mathrm{A} 050$ & Campodarbe & Priabonian & Set J2 & -4.79 & -1.02 & -3.52 & -0.02 & 458 (Fig. 6) \\
\hline & A103 & Belsue-Atarès & Bartonian & Set J3 & & & -4.81 & 0.11 & 507 (Fig. 4) \\
\hline & A054 & Belsue-Atarès & Bartonian & Set J3 & -2.91 & -1.38 & -5.81 & -0.05 & 465 (Fig. 4) \\
\hline & A104 & Belsue-Atarès & Bartonian & Set $\mathrm{J} 2$ & -4.65 & -2.61 & -5.11 & -1.53 & 511 (Fig. 4) \\
\hline & $\mathrm{A} 001$ & Arguis & Bartonian & Set $\mathrm{J} 2$ & -3.48 & -1.41 & -3.19 & -0.9 & 433 (Fig. 4) \\
\hline & A003 & Arguis & Bartonian & Set F1 & -3.53 & -8.19 & -3.91 & -0.97 & 433 (Fig. 7) \\
\hline & A004 & Arguis & Bartonian & Set F1 & -3.4 & -1.47 & & & 433 (Fig. 7) \\
\hline & A005 & Arguis & Bartonian & Set F1 & -3.55 & -1.49 & -3.77 & -1.55 & 433 (Fig. 7) \\
\hline & A008 & Arguis & Bartonian & Set J3 & -4.35 & -1.48 & -4.16 & -1.14 & 433 (Fig. 4) \\
\hline & A009 & Arguis & Bartonian & Set F1 & 2.66 & -1.04 & & & 433 (Fig. 7) \\
\hline & A010 & Arguis & Bartonian & Set F1 & -3.26 & -0.51 & -3 & 0.02 & 433 (Fig. 7) \\
\hline & A011 & Arguis & Bartonian & Set J2 & -2.31 & -0.76 & -3.87 & 0.12 & 433 (Fig. 4) \\
\hline & $\mathrm{A} 012$ & Arguis & Bartonian & Set F1 & -2.54 & -0.78 & -3.35 & -0.72 & 433 (Fig. 7) \\
\hline & A013 & Arguis & Bartonian & Set J2 & -2.51 & -0.78 & -4.72 & -1.7 & 433 (Fig. 4) \\
\hline din & A013 & Arguis & Bartonian & Set J2 & -2.51 & -0.78 & -4.67 & -1.37 & 433 (Fig. 4) \\
\hline & A015 & Arguis & Bartonian & Set J1 & -2.94 & -0.29 & $x$ & & 434 (Fig. 4) \\
\hline & A020 & Arguis & Bartonian & Set J4 & -3.79 & -0.23 & -3.99 & -0.46 & 436 (Fig. 4) \\
\hline & A021 & Arguis & Bartonian & Set J3 & -2.86 & -0.77 & -3.69 & -0.29 & 436 (Fig. 4) \\
\hline & A022 & Arguis & Bartonian & Set F2 & -2.96 & -0.9 & -3.35 & -0.72 & 439 (Fig. 7) \\
\hline & A071 & Arguis & Bartonian & Set J2 & -3.56 & -1.46 & -3.61 & -0.23 & 476 (Fig. 4) \\
\hline & $\mathrm{A} 072$ & Arguis & Bartonian & Set J2 & -2.43 & -1.19 & -2.55 & -0.26 & 476 (Fig. 4) \\
\hline & A073 & Arguis & Bartonian & Set J3 & -2.85 & -0.82 & -3.09 & -0.28 & 477 (Fig. 4) \\
\hline & A077 & Arguis & Bartonian & Set $\mathrm{J} 2$ & -2.7 & -1.04 & -4.47 & -0.75 & 482 (Fig. 4) \\
\hline & A077 & Arguis & Bartonian & Set J3 & -2.43 & -1.23 & -4.47 & -0.75 & 482 (Fig. 4) \\
\hline & A078 & Arguis & Bartonian & Set J3 & -2.37 & -1.64 & & & 482 (Fig. 4) \\
\hline & A107 & Arguis & Bartonian & Set J3 & -2.93 & -1.13 & & & 513 (Fig. 4) \\
\hline & A121 & Arguis & Bartonian & Set F3 & -0.66 & 0.48 & -3.03 & 0.43 & 522 (Fig. 7) \\
\hline & A124 & Arguis & Bartonian & Set F2 & -3.16 & -0.64 & -4.45 & 0.28 & 523 (Fig. 7) \\
\hline & A128 & Arguis & Bartonian & Set J2 & -3.08 & -1.00 & -3.4 & -1.44 & 527 (Fig. 4) \\
\hline & A031 & Guara & Lutetian & Set F2 & -5.8 & 1.88 & -1.66 & 2.55 & 444 (Fig. 7) \\
\hline & A032 & Guara & Lutetian & Set F3 & -8.45 & -0.34 & -1.42 & 2.38 & 445 (Fig. 7) \\
\hline & A033 & Guara & Lutetian & Set F3 & -3.99 & 2.25 & -2.73 & 0.69 & 445 (Fig. 7) \\
\hline & A037 & Guara & Lutetian & Set J2 & 0.38 & 2.34 & -1.62 & 1.83 & 445 (Fig. 4) \\
\hline & A056 & Guara & Lutetian & Set J3 & -8.99 & 0.57 & -5.94 & -0.74 & 467 (Fig. 4) \\
\hline & A057 & Guara & Lutetian & Set J5 & -4.19 & 0.66 & -5.04 & -0.41 & 467 (Fig. 4) \\
\hline & A060 & Guara & Lutetian & Set J5 & -4.23 & 0.9 & -5.45 & -0.59 & 467 (Fig. 4) \\
\hline & A060 & Guara & Lutetian & Set J5 & -3.75 & 0.9 & -4.97 & -0.27 & 467 (Fig. 4) \\
\hline & A061 & Guara & Lutetian & Set J5 & -4.74 & 0.46 & -5.58 & -0.82 & 469 (Fig. 4) \\
\hline & A064 & Guara & Lutetian & Set 12 & -2.52 & 1.07 & -2.08 & 0.23 & 470 (Fig. 4) \\
\hline & A064 & Guara & Lutetian & Set J2 & -2.66 & 1.12 & & & 470 (Fig. 4) \\
\hline & A064 & Guara & Lutetian & Set J5 & -8.29 & -3.24 & & & 470 (Fig. 4) \\
\hline & A066 & Guara & Lutetian & Set J3 & -2.42 & 1.01 & & & 472 (Fig. 4) \\
\hline & A066 & Guara & Lutetian & Set J3 & -1.94 & -0.31 & & & 472 (Fig. 4) \\
\hline & A067 & Guara & Lutetian & Set J1 & -10.4 & -3.71 & -3.52 & -0.02 & 473 (Fig. 4) \\
\hline & A068 & Guara & Lutetian & Set J3 & -1.03 & 1.62 & -2.36 & 1.36 & 474 (Fig. 4) \\
\hline & $\mathrm{A} 070$ & Guara & Lutetian & Set J3 & -2.19 & 1.26 & -2.51 & 0.72 & 475 (Fig. 4) \\
\hline inio & A087 & Guara & Lutetian & Set J5 & -6.14 & -0.41 & -5.1 & 1.05 & 497 (Fig. 4) \\
\hline & A088 & Guara & Lutetian & Set J1 & -8.49 & -5.17 & & & 497 (Fig. 4) \\
\hline$p e^{e^{x}}$ & A089 & Guara & Lutetian & Set J3 & -7.91 & 1.81 & & & 498 (Fig. 4) \\
\hline & A091 & Guara & Lutetian & Set J2 & -7.67 & 0.92 & -6.12 & 0.38 & 503 (Fig. 4) \\
\hline & A094 & Guara & Lutetian & Set J1 & -8.8 & -4.56 & -6.7 & -1.27 & 499 (Fig. 4) \\
\hline & A097 & Guara & Lutetian & ??? & -3.13 & -3.28 & -2.41 & 0.22 & 503 (Fig. 4) \\
\hline & A100 & Guara & Lutetian & ??? & -5.39 & 0.8 & -1.85 & 0.67 & 503 (Fig. 4) \\
\hline & A100 & Guara & Lutetian & Set $\mathrm{J} 2$ & 2.1 & 0.98 & -1.85 & 0.67 & 503 (Fig. 4) \\
\hline & A109 & Guara & Lutetian & Set J3 & -0.71 & 2.38 & -3.12 & 1.83 & 515 (Fig. 4) \\
\hline & A115 & Guara & Lutetian & Set J3 & -8.74 & 2.27 & & & 519 (Fig. 4) \\
\hline & A118 & Guara & Lutetian & Set J5 & -1.96 & 2.38 & & & 520 (Fig. 4) \\
\hline & A119 & Guara & Lutetian & ??? & -2.55 & 2.14 & & & 520 (Fig. 4) \\
\hline & A086 & Adraen-Bona & Cretaceous & Set $\mathrm{J} 2$ & -5.43 & 0.56 & -3.9 & 1.49 & 493 (Fig. 4) \\
\hline & A082 & Tremp & Cretaceous & Set J5 & -7.08 & -6.34 & & & 489 (Fig. 4) \\
\hline & A083 & Tremp & Cretaceous & Set J5 & -7.26 & -7.2 & & & 489 (Fig. 4) \\
\hline & A084 & Tremp & Cretaceous & Set J4 & -6.71 & -7.77 & -3.77 & -6.29 & 490 (Fig. 4) \\
\hline & A131 & Triassic & Triassic & Set J1 & -7.23 & -3.51 & -3.28 & 2.65 & 553 (Fig. 4) \\
\hline & A131 & Triassic & Triassic & Set J4 & -7.65 & -4.09 & -3.28 & 2.65 & 553 (Fig. 4) \\
\hline & A132 & Triassic & Triassic & ??? & -6.73 & -5.43 & -4.11 & -1.37 & 555 (Fig. 4) \\
\hline & A133 & Triassic & Triassic & & & & -5.78 & 0.21 & 555 (Fig. 4) \\
\hline
\end{tabular}




\begin{tabular}{|c|c|c|c|c|}
\hline Site number & Longitude (decimal) & Latitude (decimal) & Formation & Age \\
\hline 4446 & $\begin{array}{l}-0.398945 \\
\end{array}$ & le & Campodarbe & $\begin{array}{l}\text { Priabonian } \\
\text { Pian }\end{array}$ \\
\hline 447 & -0.407133 & 42.330704 & Campodarbe & Priabonian \\
\hline 449 & -0.402130 & 42.329652 & Campodarbe & Priabonian \\
\hline 450 & -0.401991 & 42.329628 & Campodarbe & Priabonian \\
\hline 452 & -0.401818 & 42.329522 & Campodarbe & Priabonian \\
\hline 453 & -0.401759 & 42.329546 & Campodarbe & Priabonian \\
\hline 455 & -0.401005 & 42.329284 & Campodarbe & Priabonian \\
\hline 458 & -0.400551 & 42.329169 & Campodarbe & Priabonian \\
\hline 528 & -0.393591 & 42.342126 & Campodarbe & Priabonian \\
\hline 459 & -0.393884 & 42.325935 & Belsué-Atarès & Bartonian \\
\hline 464 & -0.394159 & 42.325990 & Belsué-Atarès & Bartonian \\
\hline 465 & -0.394251 & 42.326038 & Belsué-Atarès & Bartonian \\
\hline 507 & -0.412320 & 42.328541 & Belsué-Atarès & Bartonian \\
\hline 511 & -0.412357 & 42.328458 & Belsué-Atarès & Bartonian \\
\hline 43 & -0.414050 & 42.326917 & Arguis & Bartonian \\
\hline 44 & -0.426783 & 42.325333 & Arguis & Bartonian \\
\hline 433 & -0.413300 & 42.326370 & Arguis & Bartonian \\
\hline 434 & -0.411983 & 42.326212 & Arguis & Bartonian \\
\hline 436 & -0.414191 & 42.326608 & Arguis & Bartonian \\
\hline 439 & -0.414035 & 42.326563 & Arguis & Bartonian \\
\hline 476 & -0.412080 & 42.326619 & Arguis & Bartonian \\
\hline 477 & -0.412371 & 42.326508 & Arguis & Bartonian \\
\hline 482 & -0.412419 & 42.327050 & Arguis & Bartonian \\
\hline 513 & -0.412389 & 42.326222 & Arguis & Bartonian \\
\hline 522 & -0.420804 & 42.327150 & Arguis & Bartonian \\
\hline 523 & -0.421153 & 42.327128 & Arguis & Bartonian \\
\hline 527 & -0.424152 & 42.325338 & Arguis & Bartonian \\
\hline 25 & -0.40305 & 42.305800 & Guara & Lutetian \\
\hline 26 & -0.40723 & 42.314360 & Guara & Lutetian \\
\hline 27 & -0.407833 & 42.314367 & Guara & Lutetian \\
\hline 28 & -0.406483 & 42.313517 & Guara & Lutetian \\
\hline 31 & -0.404667 & 42.308367 & Guara & Lutetian \\
\hline 32 & -0.403767 & 42.307033 & Guara & Lutetian \\
\hline 33 & -0.403067 & 42.305917 & Guara & Lutetian \\
\hline 34 & -0.410050 & 42.323300 & Guara & Lutetian \\
\hline 35 & -0.414367 & 42.324433 & Guara & Lutetian \\
\hline 36 & -0.428350 & 42.297539 & Guara & Lutetian \\
\hline 37 & -0.426886 & 42.298922 & Guara & Lutetian \\
\hline 38 & -0.428286 & 42.301444 & Guara & Lutetian \\
\hline 39 & -0.411600 & 42.317750 & Guara & Lutetian \\
\hline 40 & -0.412467 & 42.321100 & Guara & Lutetian \\
\hline 42 & -0.414767 & 42.322667 & Guara & Lutetian \\
\hline 45 & -0.411300 & 42.325400 & Guara & Lutetian \\
\hline 46 & -0.422067 & 42.306017 & Guara & Lutetian \\
\hline 51 & -0.409400 & 42.309736 & Guara & Lutetian \\
\hline 52 & -0.402764 & 24.300739 & Guara & Lutetian \\
\hline 136 & -0.412183 & 42.326367 & Guara & Lutetian \\
\hline 137 & -0.411233 & 42.329683 & Guara & Lutetian \\
\hline 138 & -0.428667 & 42.305850 & Guara & Lutetian \\
\hline 139 & -0.448000 & 42.303667 & Guara & Lutetian \\
\hline 141 & -0.446800 & 42.294267 & Guara & Lutetian \\
\hline 142 & -0.442767 & 42.310567 & Guara & Lutetian \\
\hline 144 & -0.393750 & 42.345333 & Guara & Lutetian \\
\hline 145 & -0.418917 & 42.324983 & Guara & Lutetian \\
\hline 146 & -0.402833 & 42.335867 & Guara & Lutetian \\
\hline 444 & -0.412102 & 42.325097 & Guara & Lutetian \\
\hline 445 & -0.412098 & 42.325157 & Guara & Lutetian \\
\hline 467 & -0.405834 & 42.312462 & Guara & Lutetian \\
\hline 469 & -0.405920 & 42.312555 & Guara & Lutetian \\
\hline 470 & -0.405842 & 42.312665 & Guara & Lutetian \\
\hline 472 & -0.405998 & 42.312688 & Guara & Lutetian \\
\hline 473 & -0.406108 & 42.312823 & Guara & Lutetian \\
\hline 474 & -0.406552 & 42.313484 & Guara & Lutetian \\
\hline 475 & -0.406526 & 42.313602 & Guara & Lutetian \\
\hline 497 & -0.419564 & 42.306512 & Guara & Lutetian \\
\hline 498 & -0.420014 & 42.306393 & Guara & Lutetian \\
\hline 499 & -0.420358 & 42.306254 & Guara & Lutetian \\
\hline 500 & -0.429013 & 42.304032 & Guara & Lutetian \\
\hline 503 & -0.403275 & 42.306514 & Guara & Lutetian \\
\hline 515 & -0.416279 & 42.323905 & Guara & Lutetian \\
\hline 519 & -0.414092 & 42.322768 & Guara & Lutetian \\
\hline 520 & -0.412027 & 42.319628 & Guara & Lutetian \\
\hline 493 & -0.411017 & 42.309405 & Adrean-Bona & Cretaceous \\
\hline 489 & -0.407789 & 42.310467 & Tremp & Cretaceous \\
\hline 490 & -0.407872 & 42.310662 & Tremp & Cretaceous \\
\hline 553 & -0.401047 & 42.285117 & Triassic & Triassic \\
\hline 555 & -0.401272 & 42.286006 & Triassic & Triassic \\
\hline
\end{tabular}

